\title{
Glioblastoma pharmacotherapy: A multifaceted perspective of conventional and emerging treatments (Review)
}

\author{
ANI-SIMONA SEVASTRE ${ }^{1 *}$, ALEXANDRA COSTACHI ${ }^{2 *}$ LIGIA GABRIELA TATARANU $^{3}$, \\ CORINA BRANDUSA ${ }^{2}$, STEFAN ALEXANDRU ARTENE ${ }^{2}$, OLIVIAN STOVICEK ${ }^{4}$, \\ OANA ALEXANDRU ${ }^{5}$, SUZANA DANOIU ${ }^{6}$, VERONICA SFREDEL ${ }^{7}$ and ANICA DRICU ${ }^{2}$ \\ ${ }^{1}$ Department of Pharmaceutical Technology, Faculty of Pharmacy; ${ }^{2}$ Department of Biochemistry, Faculty of Medicine, \\ University of Medicine and Pharmacy of Craiova, 200349 Craiova; ${ }^{3}$ Department of Neurosurgery, \\ 'Bagdasar-Arseni' Emergency Clinical Hospital, 041915 Bucharest; ${ }^{4}$ Department of Pharmacology, \\ Faculty of Nursing Targu Jiu, Titu Maiorescu University of Bucharest, 210106 Targu Jiu; \\ Departments of ${ }^{5}$ Neurology, ${ }^{6}$ Pathophysiology and ${ }^{7}$ Physiology, Faculty of Medicine, \\ University of Medicine and Pharmacy of Craiova, 200349 Craiova, Romania
}

Received April 8, 2021; Accepted September 21, 2021

DOI: $10.3892 / \mathrm{etm} .2021 .10844$

\begin{abstract}
Due to its localisation, rapid onset, high relapse rate and resistance to most currently available treatment methods, glioblastoma multiforme (GBM) is considered to be the deadliest type of all gliomas. Although surgical resection, chemotherapy and radiotherapy are among the therapeutic strategies used for the treatment of GBM, the survival rates achieved are not satisfactory, and there is an urgent need for novel effective therapeutic options. In addition to single-target therapy, multi-target therapies are currently under development. Furthermore, drugs are being optimised to improve their ability to cross the blood-brain barrier. In the present review, the main strategies applied for GBM treatment in terms of the most recent therapeutic agents and approaches that are currently under pre-clinical and clinical testing were discussed. In addition, the most recently reported experimental data following the testing of novel therapies, including stem cell therapy, immunotherapy, gene therapy, genomic correction and precision medicine, were reviewed, and their advantages and drawbacks were also summarised.
\end{abstract}

Correspondence to: Professor Anica Dricu, Department of Biochemistry, Faculty of Medicine, University of Medicine and Pharmacy of Craiova, 2-4 Petru Rareş Street, 200349 Craiova, Romania E-mail: anica.dricu@live.co.uk

*Contributed equally

Abbreviations: PDGFR, platelet-derived growth factor receptor; $\mathrm{RTK}$, receptor tyrosine kinase; Rb1, retinoblastoma protein 1

Key words: glioblastoma, pathways, targeted therapy, pharmaceutics, clinical trials

\section{Contents}

1. Introduction

2. Pharmaceutical products tested in clinical trials

3. Drug therapies under development

4. Conclusions

\section{Introduction}

Although various cancer therapies have achieved promising outcomes in clinical trials, resistance to treatment remains a major obstacle (1). By unravelling the underlying mechanism in this process and developing new drugs, it is hoped that superior therapeutic strategies that can improve clinical outcomes will emerge in the near future (2-5).

Brain malignancies are associated with high rates of morbidity and mortality, which require extensive resource allocation (6). Glioma is the most common type of cancer in the primary central nervous system (CNS), comprising $>80 \%$ of all brain cancer cases, of which $46.3 \%$ are glioblastomas, according to the Central Brain Tumor Registry of the United States Statistical Report regarding primary brain and central nervous system tumours diagnosed in the United States between 2008 and 2012 (6). Low-grade gliomas include grade I tumours (such as pilocytic astrocytoma and diffuse glioma) and grade II tumours (such as astrocytoma and oligodendroglioma), whereas high-grade gliomas (HGGs) include grade III tumours (such as anaplastic astrocytomas and anaplastic oligodendrogliomas) and grade IV tumours (such as glioblastoma) (7). Glioblastoma or glioblastoma multiforme (GBM) is considered to be the deadliest and the most common primary malignancy of the CNS, comprising $16 \%$ of all primary brain tumours and up to $54 \%$ of all gliomas (6). Similar to other types of brain cancer, GBM requires sophisticated medical technology for accurate diagnosis and therapy (6). Despite the application of various multimodal therapy approaches 
combining surgery, chemotherapy and radiotherapy, GBM is typically fatal within 3-4 months of its occurrence without treatment, with a life expectancy of $\sim 14$ months with surgery and adjuvant radiation therapy (6). Therefore, there is continuous demand for the development of novel strategies to improve the survival rate of patients with GBM.

GBM can be primary (de novo) or secondary, i.e., it can also develop from grade II astrocytoma or grade III anaplastic astrocytoma (8). In addition, by using datasets generated by The Cancer Genome Atlas, a previous study identified the following four subtypes of GBM: Pro-neural; neural; classical; and mesenchymal (8). Each subtype exhibits its own unique distinctive phenotypic and gene expression profiles (8). Inefficiency of drug delivery across the blood-brain barrier (BBB) and drug resistance are the main obstacles to GBM treatment (9). Despite the availability of various treatment strategies against GBM, including chemotherapy, radiotherapy and surgical resection, the median survival time remains unsatisfactory, at only 14.6 months (10).

GBM is a highly aggressive malignant brain tumour that mainly originates from glial cells, and its current treatment options include chemotherapy, radiotherapy and neurosurgery (10-12). Rapid recurrence after therapy significantly worsens the prognosis due to the invasive properties of glioma cells (13). Temozolomide (TMZ) is currently the main chemotherapeutic agent used for the treatment of GBM (14). However, long-term TMZ administration typically results in resistance, limiting its efficacy (15). The stem-like characteristics of GBM cells are primarily responsible for its resistance to chemotherapy, immunotherapy and radiation (16). Therefore, adjuvant therapy, such as chemotherapy or immunotherapy, may be applied to overcome drug resistance and to improve the survival rates of patients with GBM (17). In the era of precision medicine, a combination of molecular techniques can also be applied to target the unique tumour characteristics of individual patients (18-20). To improve the outcome, a comprehensive list of parameters must be understood, including the GBM microenvironment, the pharmacokinetic and pharmacodynamic profiles of the drug of interest, in addition to the delivery and safety profiles (21). Although some drugs (TMZ, lomustine, carmustine and bevacizumab) have obtained Food and Drug Administration (FDA) approval for GBM treatment, others are currently at different stages of clinical trial testing (22). In addition, despite extensive scientific research, a clear standard-of-care (SOC) guideline for recurrent GBM is lacking. Although drug resistance poses numerous challenges, there is hope that future treatments may prove more effective for patients with GBM.

Consistent with other types of cancer, the survival rate of GBM can be improved through early diagnosis (6); however, this is rare in this disease (6). Due to the presence of highly invasive cells, surgery cannot be applied in a large number of cases (23). In addition, due to the high degree of redundancy in the signalling pathways that are dysregulated in GBM (8), a high rate of efficacy cannot be achieved by only applying single-target therapy. Monotherapy is considered to be inadequate due to resistance triggered by the various compensatory feedback mechanisms and the low number of specific predictive biomarkers available (9). Therefore, designing a multi-targeted therapeutic approach for patients with GBM currently remains a challenge. Furthermore, the targeted site [receptor tyrosine kinases (RTK), PI3K signalling, retinoblastoma protein ( $\mathrm{Rb})$ or p53 signalling pathways] requires a complex formulation to obtain the correct molecular structure and highly precise doses with the ability to readily cross the BBB (24).

The DNA alkylating chemotherapeutic agent TMZ is the first-line and SOC treatment method for GBM, both as monotherapy or in combination with radiotherapy (10). The currently used SOC guideline for GBM consists of maximal safe resection (the safest surgical approach, such as biopsy, different degrees of subtotal resection, or gross total resection), radiotherapy and chemotherapy using TMZ (10-12). After surgery, the treatment regimen consists of 6 weeks of radiotherapy in the surgical cavity with TMZ treatment, followed by adjuvant therapy, consisting of six cycles in total of TMZ treatment at a dose of $150-200 \mathrm{mg} / \mathrm{m}^{2}$ for 5 days during each 28-day cycle (10). TMZ is an alkylating chemotherapeutic agent that can be orally administered and acts by causing DNA damage, which triggers a signalling cascade that leads to the apoptosis of the malignant cells (9). $\mathrm{O}^{6}$-methylguanine methyltransferase (MGMT), a DNA repair enzyme, is responsible for transferring the methyl group from a guanine to a cysteine residue, counteracting chemotherapy-induced DNA alkylation and, therefore, leading to cancer drug resistance (9). Furthermore, another FDA-approved treatment method for GBM is the implantation of biodegradable wafers made of polifeprosan 20 with carmustine into the resection cavity (11). These wafers are implants containing carmustine and a biodegradable copolymer (polifeprosan-a polyanhydride copolymer consisting of poly [bis (p-carboxyphenoxy)] propane and sebacic acid at a 20:80 molar ratio), to control the release rate of carmustine. These wafers are white to pale yellow, $1.45-\mathrm{cm}$ in diameter and with a thickness of 1-mm (25). Carmustine causes cross-links in DNA and RNA, inhibiting DNA synthesis, RNA production and translation. In addition, carmustine binds to glutathione reductase, leading to cell death. However, the risk of infection and impaired wound healing are complications that limit its use (11).

Recent studies have been focusing on developing novel biomaterials that can efficiently deliver TMZ to the active site. Implantable microspheres loaded with TMZ that can release this drug in a sustained manner have been previously studied (26). In addition, functionalised TMZ nanoparticles have been successfully developed, including liposomes functionalised with transferrin (27), chitosan nanoparticle functionalised with biotin (28), poly-lactide-co-glycolide nanoparticle functionalised with a monoclonal antibody against transferrin receptor (29), mesopore silica nanoparticles (30), gold-coated nanofibers (31) and magnetite nanoparticles (32). To improve the bioavailability of active drugs by preventing rapid degradation or drug resistance, other strategies have been used in addition to nanotechnology, such as synergistic substances or tumour-targeting peptides. TMZ may be either administered alone, or in combination with radiotherapy or with other active substances, including acridone derivatives (33), chlorotoxin (28), the bromodomain inhibitor JQ1 (27) or doxorubicin (18), with the aim of improving the treatment outcomes.

When tumour-bearing mice were treated with transferrin nanoparticles loaded with TMZ and the bromodomain 
inhibitor JQ1, the DNA damage and cell apoptosis increased, which was associated with an increase in survival compared with equivalent free drug treatment (27).

A synergistic approach has been studied using acridone derivatives combined with TMZ. This combination was found to exert major tumour cytotoxic effects, effectively suppressing malignant cell proliferation in both sensitive and resistant tumour cell subpopulations (33).

TMZ bound to nanoparticles exhibits higher stability at physiological $\mathrm{pH}$, with a half-life 7-fold longer compared with free TMZ. TMZ nanoparticles with chlorotoxin (NP-TMZ-CTX) was able to target GBM cells and achieved 2-6-fold higher uptake and 50-90\% reduction of $\mathrm{IC}_{50}$ at $72 \mathrm{~h}$ post-treatment as compared with non-targeted NP-TMZ. NP-TMZ-CTX has shown great promise in its ability to deliver a high therapeutic dose of TMZ to GBM cells, and may serve as a template for targeted delivery of other therapeutics (28).

Molecular targeting is another therapeutic strategy used for GBM, with different approaches, namely to target tubulin and EGFR to modify DNA function or to deactivate $\mathrm{NF}-\kappa \mathrm{B}(34,35)$. The majority of the targeted molecular therapies against GBM were developed to specifically inhibit tumour angiogenesis (36-38). A large number of drugs proposed for GBM therapy are anti-angiogenic agents that function by inhibiting VEGFR or platelet-derived growth factor (PDGF) receptor (PDGFR) function (36). A previous meta-analysis, which included 11 studies and 3,743 participants, did not reveal an improvement in the overall survival (OS) of patients with HGG who received anti-angiogenic therapy (36). However, an improvement in progression-free survival (PFS) was observed (36). Although the pathophysiological mechanism underlying GBM involves a large number of signalling pathways, the PI3K/AKT/mTOR pathway has been attracting particular attention, since it can regulate protein synthesis, cell proliferation, migration, angiogenesis and apoptosis (39). Previous studies have demonstrated that a dual targeting PI3K/mTOR signalling pathway or a combined therapy with PDGFR and VEGFR inhibitors were more efficient in inducing GBM cell death compared with single treatment $(40,41)$.

Immunotherapy is also becoming an important field of research in GBM. Peptide vaccines, such as Rindopepimut and SurVaxM, in addition to autologous vaccines, including Gliovac and Prophage, are potential candidates for immunotherapy against GBM $(42,43)$. In addition, oncolytic viral therapy (VT) using the parvovirus ParvOryx is an emerging strategy used for the treatment of GBM (44). Data from a previous study showed that the effects of VT were comparable to those of dendritic cell (DC)-based vaccines, with similar outcomes in comparison with standard therapy, including previous GBM single resection, subsequent radiotherapy and first-line therapy with concomitant TMZ/bevacizumab and irinotecan (44). DC-based vaccination is an immunotherapy approach used to boost the potential of the cancer patient's own immune system. Autologous DCs are obtained from monocytes in peripheral blood mononuclear cells, and then loaded with stem-like cell-associated antigens. Generally, 3-5 weeks are required for vaccine production. However, to induce a lasting and potent immune response, several conditions are required, such as the minimum number of injected DCs, a specific vaccination schedule and route of administration, details which have not yet been clearly outlined. To assess the clinical impact of immunotherapy compared with that following standard HGG treatment (surgical resection with adjuvant hyperfractionated radiotherapy and concomitant TMZ), a comprehensive meta-analysis of previous clinical trials that applied DC therapy and VT was conducted by measuring OS and PFS as the outcome parameters (1). It was found that the OS was greatly improved by DC therapy in patients with both new and recurrent HGG (1). However, VT did not confer statistically significant improvements in either OS or PFS in patients with newly diagnosed HGG. Due to the insufficient number of studies, a meta-analysis on PFS for patients with recurrent HGG who received DC vaccination and a meta-analysis of OS and PFS for patients with recurrent HGG who received VT could not be carried out $(1,45)$.

GBM stem cells (GSCs) represent another cell type in GBM that appear to be important for tumour growth, since they have been reported to be implicated in drug resistance and recurrence after therapy (46). This suggests that GSCs may be suitable targets for the development of novel therapeutic strategies (47).

In terms of drug delivery, different types of biomaterials, including nanoshells, liposomes and nanoparticles, have been developed over the past decade $(3,4)$. The ultimate aims were to accurately deliver antitumour agents to their respective targets and to improve bioavailability whilst minimising side effects $(3,4)$.

It has been widely reported that genetic and epigenetic alterations are major causes of carcinogenesis $(8,48)$. These alterations tend to overlap with the signalling pathways involved in controlling cell proliferation, cell division, apoptosis and cell motility (8). However, they may also cause alterations in other signalling networks that can indirectly promote cancer progression, including inflammation, modulation of the tumour microenvironment and angiogenesis (8). To date, three core signalling pathways have been frequently associated with GBM pathogenesis $(32,49,50)$ : The p53, Rb and RTK/Ras/PI3K pathways (Fig. 1). However, other signalling pathways and effectors may be involved in this type of malignant disease and their discovery would uncover the possibility of novel therapies in the future. The currently available therapy options for GBM (51-64) are summarised in Table I.

In the present review, the main strategies applied for GBM treatment are presented by discussing the most recent pharmacological and other medical approaches that are currently under pre-clinical and clinical examination, followed by outlining the future perspectives for optimising GBM management.

\section{Pharmaceutical products tested in clinical trials}

Although GBM is characterised by heterogeneity, analysis of genetic aberrations has identified the following three commonly dysregulated signalling pathways: Activation of the RTK/Ras/PI3K pathway; inhibition of p53; and Rb signalling (48). These are the focus of current research efforts in the search for molecular targets of GBM. Of the numerous strategies employed for GBM treatment, only a small number have successfully reached pharmaceutical marketing. Among 


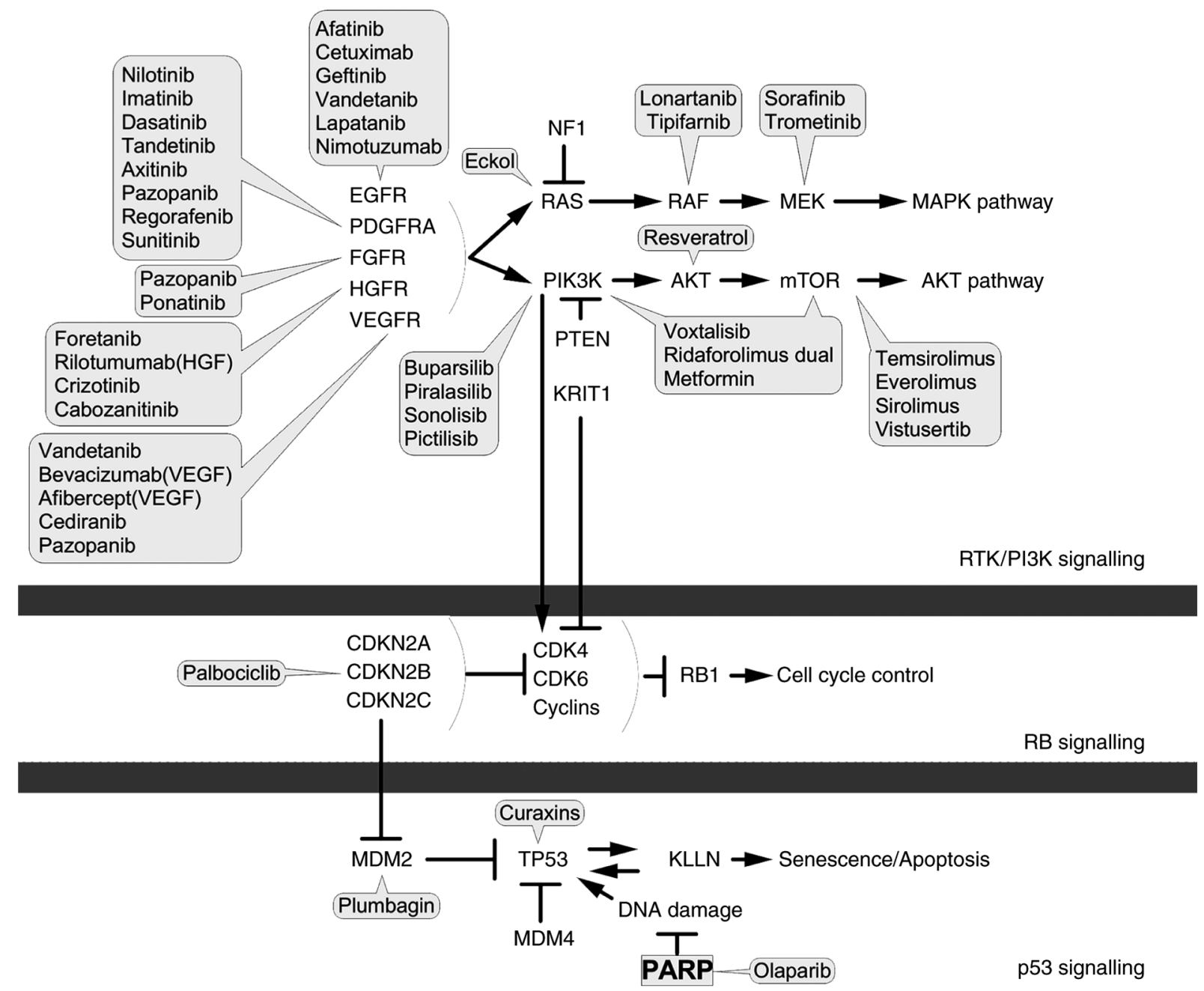

Figure 1. Glioblastoma multiforme signalling pathways. PDGFRA, platelet-derived growth factor receptor A; FGFR, fibroblast growth factor receptor; INSR, insulin receptor; NF1, neurofibromin 1; MAPK, mitogen-activated protein kinase; PIK3CA, phosphatidylinositol-4,5-bisphosphate 3-kinase catalytic subunit alpha; KRIT1, Krev interaction trapped; RTK, receptor tyrosin kinase; CDKN2A/B/C, cyclin-dependent kinase inhibitor 2A/B/C; CDK4/6, cyclin-dependent kinase 4/6; $\mathrm{Rb} 1$, retinoblastoma protein 1; MDM2/4, mouse double minute 2/4 homolog; KLLN, killin. Block arrow, inhibition; point arrow, pathway flow.

these, the following are of interest: i) Molecularly targeted therapy; ii) anti-angiogenic drugs; iii) GSC targeting; iv) microRNAs; v) immunotherapy; vi) nanotherapy; vii) gene therapy; and viii) oncolytic viruses (59). As of 2021, a number of compounds have successfully gone through all phases of drug development and have been approved for clinical testing on human subjects $(21,37,38,42,44,54,60,61,65-82)$. They are summarized in Table II.

At present, drugs targeting the RTK/Ras/PI3K, p53, Rb and TGF- $\beta$ signalling pathways are undergoing clinical trial testing, whilst those that target the Wnt (83) and unfolded protein response (84) signalling pathways remain under experimental investigation.

Chemotherapeutics. TMZ (trade names, Temodar or Temodal; Schering-Plough) (85) functions via a mechanism that is not fully understood. TMZ is an imidazotetrazine pro-drug of dacarbazine, which acts as an alkylating agent by causing double-stranded DNA breaks, in addition to inhibiting the activity of DNA repair enzymes (9). TMZ primarily exerts cytostatic and pro-senescence effects by preventing cancer cell cycle progression from the $G_{2}$ to $M$ phase, but it is generally not cytotoxic or apoptosis-inducing (86). Previous studies found that, compared with other alkylating agents, prolonged $\mathrm{TMZ}$ treatment after radiotherapy appears to be well-tolerated among patients with GBM $(10,66,87)$. However, its therapeutic efficacy is limited. Currently available clinical data suggest that significant benefits were only observed in a small percentage of patients, with a median survival extension of only 2.5 months (10). Therefore, TMZ is typically applied as a part of a complex regimen of combinatorial therapy, such as RIST (rapamycin, irinotecan, sunitinib and TMZ) (88) or CUSP9 (a therapeutic protocol that includes nine repurposed active substances: Aprepitant, minocycline, disulfiram, celecoxib, sertraline, captopril, itraconazole, ritonavir and auranofin, along with low-dose TMZ) (89).

Carmustine. Carmustine [or 1,3-bis(2-chloroethyl)-1nitrosurea] is another DNA and RNA alkylating agent that has been used for GBM therapy $(11,67)$. Gliadel ${ }^{\circledR}$ (Guilford Pharmaceuticals, Inc.) is the commercial name of biodegradable polymer wafers containing $3.85 \%$ carmustine in a polifeprosan 20 implant (11). It is designed to be inserted into the resection cavity, which then releases the active agent 
Table I. Chemical and immunological therapy options in glioblastoma multiforme.

\begin{tabular}{|c|c|c|c|}
\hline Class & Active ingredient & Mechanism & (Refs.) \\
\hline \multirow[t]{4}{*}{ Anti-angiogenics } & $\begin{array}{l}\text { Bevacizumab, panobinostat, } \\
\text { altiratinib }\end{array}$ & Target VEGF & $(19,51,52)$ \\
\hline & Trebananib & Targets tumour-associated endothelial cells & $(53)$ \\
\hline & Crenolanib, tandutinib & Inhibit PDGFR & $(22)$ \\
\hline & Enzastaurin & Inhibits protein kinases & $(54)$ \\
\hline Kinase inhibitors & Paxalisib & Inhibits PI3K and mTOR & $(55)$ \\
\hline \multirow[t]{3}{*}{ Molecularly targeted agents } & $\begin{array}{l}\text { Temozolomide, mibefradil, } \\
\text { carmustine }\end{array}$ & Alter DNA functions & $(56)$ \\
\hline & Afatinib & Inhibits EGFR & $(57)$ \\
\hline & Curaxins & p53 activator and $\mathrm{NF}-\kappa \mathrm{B}$ deactivator & $(58)$ \\
\hline \multirow[t]{2}{*}{ Vaccine-based immunotherapy } & Rindopepimut, survivin & Peptide vaccines & (59) \\
\hline & Sitoiganap, Prophage & Autologous cancer vaccines & $(60)$ \\
\hline Antibody-based immunotherapy & Asunercept, depatuxizumab & EGFR-targeting antibodies & $(61,62)$ \\
\hline Checkpoint inhibitors & Indoximod & $\begin{array}{l}\text { Inhibits indoleamine 2,3-dioxygenase } \\
\text { pathway }\end{array}$ & (63) \\
\hline Oncolytic viruses & ParvOryx & Autonomous protoparvovirus $\mathrm{H}-1$ & $(64)$ \\
\hline
\end{tabular}

directly into the target site (11). The survival benefit of carmustine has demonstrated an increased median survival time of 89.5 weeks in patients with GBM treated with carmustine wafers in combination with radiotherapy compared with radiotherapy alone $(90)$.

Among the 51 clinical studies that tested carmustine for GBM treatment, only one is ongoing (participants are being examined or are receiving an intervention), but not recruiting (potential participants are not currently being enrolled or recruited), and is currently at phase I/II. That study was undertaken to investigate the possible dosage and side effects of TMZ co-administration with carmustine, $\mathrm{O}^{6}$-benzylguanine $\left(\mathrm{O}^{6} \mathrm{BG}\right)$, radiotherapy and autologous stem cell transplantation in patients with newly diagnosed GBM (91). The results indicate that the blood and bone marrow can be chemoprotected from combined $\mathrm{O}^{6} \mathrm{BG}$ and $\mathrm{TMZ}$ chemotherapy-associated myelosuppression using gene modification with the $\mathrm{O}^{6} \mathrm{BG}-$ resistant P140K mutant MGMT. Compared with TMZ alone, the addition of $\mathrm{O}^{6} \mathrm{BG}$ to $\mathrm{TMZ}$ treatment appears to provide significant treatment gains for $\mathrm{mg}$ of TMZ dose (91).

Lomustine. Lomustine, marketed as Gleostine (Next Source Technology, LLC), is a type of nitrosourea that is orally administered during chemotherapy (92). It also functions through an alkylating mechanism (92). Despite modest PFS prolongation, the combination of lomustine and bevacizumab (a monoclonal antibody developed against VEGF) was not found to confer survival advantages compared with lomustine alone in patients with progressive GBM (68). However, recent results indicate that the combination of lomustine and TMZ may improve the survival rate compared with standard TMZ therapy in patients with newly diagnosed GBM positive for MGMT promoter methylation (20).

Targeted therapy. In GBM, several pathways have been frequently found to be altered, including the PI3K/AKT/mTOR, p53 and Rb pathways $(39,49)$, making them potential targets for GBM treatment. Although there is increasing interest in targeting the tumour microenvironment, such as blood vessels, the monocyte-macrophage-microglia compartment and $\mathrm{T}$ cells (93), improved clinical trial design by including pharmacodynamic endpoints in patient populations is required to optimise this type of treatment.

Afatinib is an orally administered, third-generation EGFR inhibitor that has been extensively studied for its potential application in GBM therapy $(57,70,94,95)$. Gefitinib, erlotinib, dacomitinib and osimertinib are also examples of EGFR inhibitors $(49,96)$. Although different strategies are used for targeting EGFR in recurrent GBM, it appears that, although the efficacy of afatinib is limited, its safety profile is manageable (94). A recent study demonstrated that afatinib in combination with TMZ inhibited the tumourigenesis of GBM cells by targeting the EGFRvIII/cMet signalling pathway (95). In addition, compared with afatinib monotherapy, its combination with TMZ was revealed to synergistically inhibit GBM cell motility, invasion, proliferation and clonogenic survival whilst inducing senescence (97).

Dasatinib is an orally administered, synthetic smallmolecule inhibitor of the Src family of tyrosine kinases (98). A previous clinical trial investigating dasatinib treatment in patients with recurrent GBM found that it was not effective (98).

Regorafenib is an orally administered inhibitor of stromal, oncogenic and angiogenic RTKs (99). REGOMA is a multicentre, open-label, randomised phase II clinical trial that was performed in Italy, which found that regorafenib treatment conferred a surprisingly good OS rate in patients with recurrent GBM, suggesting that it should be investigated in a subsequent phase III study (99).

Dianhydrogalactitol (Val-083) is a bifunctional hexitol derivative that was first introduced in 1979 for the treatment of gynaecological malignancies (100). However, it was recently 
Table II. Clinically tested drugs used in GBM treatment.

\begin{tabular}{l} 
Drug (trade name)-manufacturer \\
\hline Chemotherapeutic drugs \\
Temozolomide (Temodar)- \\
Merck KGaA \\
Carmustine (BiCNU, Gliadel \\
waffer)-Bristol Mayers Squibb, \\
Arbor Pharmaceuticals \\
Lomustine (CeeNU, Gleostine)- \\
Bristol-Myers-Squibb \\
NextSource Biotechnology \\
Targeted drugs \\
Mibefradil-Cavion/Jazz \\
Pharmaceuticals \\
Afatinib (Giotrif)-Boehringer \\
Ingelheim
\end{tabular}

Dianhydrogalactitol (Val-083)-

DelMar Pharmaceuticals

Bevacizumab (BV, Avastin,

Mvasi)-Genentech, Amgen

Tandutinib (MLN518)-

Millennium Pharmaceuticals

Enzastaurin-Eli Lilly

Cediranib (AZD2171)-

AstraZeneca

Immunotherapy drugs

Active immunotherapy

Rindopepimut (Rintega,

CDX-110)-Celldex

SurVaxM-MimiVax

Prophage (G-100, G-200, Vitespen)-Agenus

Gliovac (ERC 1671)-Epitopoietic Research Corporation

IMA950-Immatics

Biotechnologies

ICT-107-ImmunoCellular

Therapeutics

DCVax-L-Northwest

Biotherapeutics
Alkylating agent

Alkylating agent as injectable solution (BiCNU) or biodegradable polymer implant (Gliadel)

Alkylating agent

Selective blocker of T-type channels

Irreversible inhibitor of EGFR, tyrosine kinase activity and tumour cell proliferation

Binds to GBM cell DNA, leading to cell death

Human monoclonal antibody that inhibits VEGF

Inhibitor of type III receptor tyro sine kinase (PDGF receptor-b, c-Kit, Fms-like tyrosine kinase 3) Specifically targets and inhibits protein kinase $\mathrm{C}$

Inhibitor of tyrosine kinase with activity on PDGF receptors and $\mathrm{c}-\mathrm{Kit}$

Peptide vaccine

Peptide vaccine that targets survivin

Heat shock protein peptide complex-96

\section{Autologous antigens}

Immunotherapeutic multiplepeptide vaccine

Autologous dendritic cell vaccine pulsed with class I peptide from tumour-associated antigens

Dendritic cell vaccine
Nausea, vomiting, mouth sores, taste

changes, constipation, coughing,

headache and tiredness

Cerebral oedema, intracranial

hypertension and infections, seizures,

thromboembolic events

Hematological toxic events

Decreased platelet count, increased aspartate and alanine aminotransferase Grade I adverse events: Nausea, vomiting, weight loss, and fatigue. Grade II adverse events: Rash. Grade III adverse events:

Maculopapular rash and paronychia

No results reported

Fatigue, headache, hypertension and thromboembolism

Common grade 3 adverse events include hypertension, muscle weakness, lymphopenia and hypophosphatemia Aortic thrombosis, erysipelas, cerebral hemorrhage and seizures

Nausea, fatigue, diarrhea, headache, hoarseness and hypertension

All rindopepimut vaccines administered in preclinical and clinical studies were generally well accepted and toxicity never exceeded grade 2

Well-tolerated, mostly with grade 1 adverse events and no serious adverse events

Adverse events (fatigue, flu-like illness, erythema, diarrhea) in $74 \%$ of the patients, with no grade 3 or 4 events related to vaccination

Mild and transient toxicity: Grade 2 headaches and local erythema at injection site

Minor reactions at injection site, pruritus, rash, fatigue, allergic reactions, neutropenia, anaemia and anaphylaxis

Well-tolerated, with no difference between the treatment and control groups regarding adverse events Mild side effects: Skin reactions, redness, pain and swelling at the site injection 
Table II. Continued.

\begin{tabular}{|c|c|c|c|}
\hline Drug (trade name)-manufacturer & Mechanism & Side effects & (Refs.) \\
\hline \multicolumn{4}{|l|}{ Passive immunotherapy } \\
\hline Depatux-M (ABT-414)-AbbVie & $\begin{array}{l}\text { Antibody-drug conjugate that } \\
\text { binds to EGFR }\end{array}$ & $\begin{array}{l}\text { Blurred vision, photophobia and eye pain } \\
\text { were reported by all patients recruited }\end{array}$ & $(21)$ \\
\hline $\begin{array}{l}\text { Asunercept (APG101, CAN-008)- } \\
\text { Apogenix }\end{array}$ & Blocker of CD95 pathway & No serious adverse events & $(61)$ \\
\hline $\begin{array}{l}\text { MEDI-3617, MEDI-575- } \\
\text { MedImmune }\end{array}$ & Novel anti-PDGFRA antibodies & Prolonged grade 3 edema & $(38)$ \\
\hline $\begin{array}{l}\text { Sirolimus (Rapamune)-PF } \\
\text { PRISM CV }\end{array}$ & mTOR inhibitor & No severe toxicity in any of the patients & (79) \\
\hline \multicolumn{4}{|l|}{ Nanotherapy-based drugs } \\
\hline Nanocell Doxorubicin-EnGeneIC & $\begin{array}{l}\text { Minicell with doxorubicin } \\
\text { conjugated against EGFR }\end{array}$ & Well-tolerated, no dose limiting toxicity & $(80)$ \\
\hline \multicolumn{4}{|l|}{ Viruses } \\
\hline ParvOryx (H-1PV)-Oryx GmBH & Oncolytic virus & $\begin{array}{l}\text { No dose-dependent side effects and no } \\
\text { dose-limiting toxicity }\end{array}$ & $(44)$ \\
\hline \multicolumn{4}{|l|}{ Gene therapy } \\
\hline $\begin{array}{l}\text { TOCA511 combined with } \\
\text { TOCAFC-Tocagen }\end{array}$ & $\begin{array}{l}\text { Retroviral replicating vector, } \\
\text { permanent integration into the } \\
\text { cancer cell genome }\end{array}$ & Bone marrow depression & $(81)$ \\
\hline Veledimex-Ziopharm Oncology & $\begin{array}{l}\text { Control system that can switch on } \\
\text { human IL-12 gene therapy on } \\
\text { demand }\end{array}$ & $\begin{array}{l}\text { Well-tolerated, decreased peripheral } \\
\text { lymphocytes and platelets, elevated liver } \\
\text { transaminases }\end{array}$ & $(82)$ \\
\hline
\end{tabular}

GBM, glioblastoma multiforme; PDGFR, platelet-derived growth factor receptor.

rediscovered as a potential treatment option for TMZ-resistant GBM (101). It is currently undergoing phase II examination in patients with bevacizumab-naïve, MGMT-unmethylated recurrent GBM (101).

Mibefradil selectively blocks T-type calcium channels and slows cancer cell proliferation, but does not induce apoptosis (102). Therefore, this drug is typically used in combination with other chemotherapeutic agents, such as TMZ, or with other therapeutic methods, such as radiotherapy (102). A previous phase I study that examined the use of mibefradil dihydrochloride, which was administered together with hypo-fractionated radiation, for patients with recurrent GBM, suggested that it could be safely co-administered, with pharmacologically effective concentrations detected in the resected area of the brain (17 days/200 mg/day mibefradil) (103). In 2017, mibefradil completed phase I clinical trial testing for GBM treatment in combination with TMZ or radiotherapy (104) and is ready to enter phase II trials.

Anti-angiogenic agents. GBM is characterised by extensive microvascular proliferation, the presence of pro-angiogenic factors and high levels of VEGF activation (8). Therefore, a number of different agents have been investigated to exploit these characteristics and to expand upon the currently limited treatment options. As such, numerous inhibitors of VEGF and pro-angiogenic signalling have been tested in previous clinical trials. However, with the exception of enzastaurin and cediranib (105), none were able to progress further than phase II of clinical testing. Due to the development of drug resistance, the responses to anti-angiogenic agents are rarely durable (36). Alternative angiogenic mechanisms are frequently activated to trigger the generation of new blood vessels (36). In addition, local hypoxia has been reported to activate alternative pro-angiogenic pathways involving angiopoietin-1, EGF, fibroblast growth factor, granulocyte colony-stimulating factor, insulin-like growth factor, PDGF, stromal cell-derived factor-1 and TGF (106). Therefore, targeting multiple signalling pathways or concomitant anti-angiogenic agent administration may prevent the development of resistance and prolong patient survival (36).

Bevacizumab (Avastin) is a human monoclonal antibody that functions as an inhibitor of VEGF (38). It was approved by the FDA as a single agent for the second-line treatment of advanced GBM (107). However, clinical trial data showed that the survival rate following bevacizumab treatment was not prolonged for $>14.5$ months (51). Different combinations of bevacizumab and other drugs are currently under investigation to improve therapeutic efficacy. A study performed in 2019 revealed that patients with recurrent GBM may benefit from a triple-drug therapy regimen consisting of bevacizumab, irinotecan and TMZ plus tumour-treating fields (TTFields; cancer treatment strategy that uses alternating electric fields of intermediate frequency and low intensity to disrupt cell division) (108). By contrast, recent results from another randomised phase I trial and placebo-controlled phase II trial, which investigated the administration of bevacizumab and 
dasatinib to patients with recurrent GBM, demonstrated that, despite Src signalling up-regulation, bevacizumab in combination with dasatinib did not significantly improve patient outcomes compared with bevacizumab alone (109).

Ranibizumab, marketed as Lucentis, is the Fab fragment derived from the parent molecule of bevacizumab (110). It was approved by FDA for the treatment of age-related macular degeneration (110) and may represent a viable option for future GBM trials.

Tandutinib (MLN518) is piperazinyl quinazoline that was designed to inhibit type III RTKs (111). Data from a previous phase II study revealed that, after oral administration, tandutinib was distributed to the brain, where its concentrations were higher compared with those in the plasma (111). Unfortunately, this particular study was closed due to lack of efficacy (111).

Cediranib (AZD2171) is a tyrosine kinase inhibitor that mainly targets c-Kit and PDGFR (37). The results of recent clinical trials showed no improvements in the survival rate when cediranib was added to the lomustine alone treatment plan, compared with that in the group treated with lomustine alone $(37,112)$. By contrast, data from another study showed that combined treatment with cediranib and radiotherapy improved the PFS and OS by improving tumour perfusion, compared with chemotherapy alone (113).

Enzastaurin specifically targets and inhibits protein kinase $\mathrm{C}$, which in turn suppresses cell proliferation and tumour growth (114). A clinical trial commenced in 2019 to examine the effects of the combination of enzastaurin and TMZ during and following radiotherapy on patients with newly diagnosed GBM, with or without the novel genomic biomarker denovo genomic marker 1 , but no results have yet been reported (115). The results from recent clinical studies using enzastaurin at different combinations did not appear to be promising $(114,115)$. Compared with other therapeutic agents, including bevacizumab, TMZ and lomustine, the survival rate did not improve following enzastaurin therapy (115).

Immunotherapy. Although immunotherapy achieved some notable successes in the treatment of other types of cancer such as skin, lung or breast cancer (116-118), it remains an emerging area of research in the GBM field. Immunotherapy in GBM includes antibody-mediated treatment, immune stimulation, vaccines and adoptive cell therapy (59). To date, none of the phase III immunotherapy-based clinical trials $(119,120)$ have demonstrated efficacy and, therefore, no FDA-approved immunotherapy against GBM currently exists. Given the challenges faced, a combinatorial approach is required. In addition, due to the high risk of recurrence, biomarker identification for patient selection and disease monitoring is essential (59). A search for 'glioblastoma' and 'immunotherapy' in the ClinicalTrials.gov database (April 2021) (120) yielded a list of 123 clinical trials that involved the following: DC vaccines; synthetic peptide vaccines; autologous T-cell transfer; gene therapy; T-cell transfer combined with tumour cell lysate vaccine; autologous natural killer (NK) or NKT cell transfer; allogeneic T-cell transfer; and immunosuppressive checkpoints (115). Furthermore, there are currently 20 ongoing (not recruiting) clinical trials worldwide that are examining the potential application of immunotherapeutic approaches for GBM treatment (115). Despite the limitations of this search, the relatively high number reflects the extensive interest in anti-GBM immunotherapy.

Active immunotherapy. Extensive research into the mechanism underlying tumour-induced immune suppression led to the discovery of the benefits of targeting immunosuppressive checkpoints, some of which are currently being tested in clinical trials on GBM $(64,75)$. Results from pre-clinical studies demonstrated that several immunotherapeutic strategies can be effectively applied to animal models of GBM, including gene therapy, passive immunotherapy, adoptive T-cell transfer targeting tumour antigens or modified to express chimeric antigen receptors, inhibition of immune checkpoints, active immunotherapy, and using peptide or DC vaccines $(74,121)$.

Rindopepimut (CDX-110) is a peptide vaccine that was designed for patients expressing EGFRvIII, a mutant EGFR that is absent in healthy cells (122) and is present in 20-30\% of patients with GBM (123). Findings from previous phase I and II clinical trials demonstrated longer PFS and OS among patients who were EGFRvIII-positive compared with those in patients who were negative for this EGFR mutant (123). However, these results were not consistent with those found in the subsequent phase III clinical trial, where the OS rate was similar between the Rindopepimut + TMZ and the TMZ alone groups (122).

Prophage (G-100, G-200 and Vitespen) contains a heat shock protein peptide complex-96 (43). This is a vaccine that was created using tumour tissue collected from the patient, making it a personalised, patient-specific vaccine (43). In a previous phase II clinical trial, patients with GBM who underwent G-100 treatment and standard therapy (TMZ) exhibited increased PFS and OS, suggesting clinical efficacy (124). However, a larger cohort is required to verify this potential efficacy (43).

SurVaxM is another peptide vaccine, which targets survivin, a cell-survival protein present in 95\% of GBMs (75). In 2016, a clinical study on patients with recurrent GBM demonstrated its safety and efficacy, which was shown by the increased PFS and OS observed compared with those in patients treated with chemotherapy alone (TMZ) (75). In March 2020, a phase II study was initiated, which tested the effects of SurVaxM and pembrolizumab on patients with GBM at the first recurrence (125). The aim was to assess its clinical activity, safety profile and tolerability (125). No results have yet been reported for this clinical trial.

Gliovac (ERC-1671) contains autologous antigens obtained from surgically removed tumour tissues from the patient and is administered in combination with allogeneic antigens obtained from other patients with GBM (43). In a previous phase I study, all patients treated with Gliovac survived for 6 months after treatment initiation compared with the control group, in which only $33 \%$ of the patients remained alive at 6 months (42). As of March 2021, Gliovac is being investigated in a phase II clinical trial.

IMA950 is a multi-peptide vaccine that has been specifically developed for GBM immunotherapy (76). It consists of tumour-associated peptides from human leukocyte antigen (HLA) surface receptors obtained from the primary human GBM tissue (126). A phase I clinical trial involving patients 
positive for HLA-A*02 reported an antitumour immune response, but no effects on the survival rate were observed (76).

DC immunotherapy is an emerging strategy for the treatment of GBM (77). Recently, phase I and II clinical trials testing DC immunotherapy were conducted on patients with newly diagnosed and recurrent GBM, prior to observing its prognostic effects. The results demonstrated that DC immunotherapy caused tumour shrinkage and elevated numbers of tumour-infiltrating $\mathrm{CD} 8^{+}$lymphocytes. The study concluded that patients with malignant glioma may benefit from DC-tumour immunotherapy, but this strategy may cause transient, albeit reversible, high levels of serum aspartate aminotransferase and alanine aminotransferase (127).

ICT-107 is an autologous DC vaccine pulsed with class I peptides from tumour-associated antigens (TAAs) designed to target six different TAAs (77). A clinical trial involving ICT-107 administration in patients with GBM revealed promising results regarding safety, reporting low-grade (grade 1) adverse events such as fatigue, flushing, pruritus, skin rash and erythema (128).

Northwest Biotherapeutics recently developed the DCVax-L vaccine, which is currently undergoing phase III trial testing in patients with newly diagnosed GBM (129). This vaccine contains a combination of autologous tumour antigens and antigens from the patient (130). Longer OS was found according to data from a previous phase I/II trial, with mild vaccination-related side effects also observed (130).

Passive immunotherapy. Adoptive immunotherapy and serotherapy are examples of passive immunotherapy strategies $(130,131)$. Since VEGF and EGF are highly expressed in GBM (35), recombinant humanised monoclonal VEGFR antibodies and anti-EGFRvIII antibodies represent an area of investigation in this field.

Asunercept (APG101 and CAN-008) inhibits the Fas (CD95) pathway (61). A previous phase II clinical trial revealed that asunercept combined with radiotherapy increased the PFS and the PFS at 6 months compared with those in the group treated with radiotherapy alone (132). Furthermore, the combination of asunercept and radiation also significantly prolonged the time to deterioration and maintained a higher quality of life compared with the radiotherapy alone group (133). However, these findings require further verification in a subsequent phase III clinical trial including a larger number of patients.

Depatux-M (depatuxizumab mafodotin, ABT-414) is an EGFR antibody-drug conjugate (62). Once internalised, it releases the anti-microtubule agent monomethyl-auristatin $\mathrm{F}$, which triggers tumour cell death (62). In a phase I clinical trial, the adverse effects of Depatux-M and TMZ combined treatment were similar to those following TMZ treatment alone (134). In March 2021, a recent phase III clinical trial undertaken to evaluate Depatux-M for the treatment of newly diagnosed GBM was discontinued due to futility, having failed to demonstrate a survival benefit. Of the patients included in that study, $85 \%$ had discontinued Depatux-M, mainly due to disease progression (135).

MEDI-3617 and MEDI-575 are two anti-platelet-derived growth factor receptor $\alpha$ (PDGFRA) antibodies that were developed for GBM therapy $(38,136)$. However, a phase II clinical study showed that although MEDI-575 was well-tolerated, it did not exhibit any significant clinical activity (136).

Nanocarriers. Nanomedicine is a rapidly evolving field, which entails the combination of nanotechnology, biomedicine and pharmacology $(3,4)$. Several attempts have been made to apply nanomedicine to the treatment of GBM. In 2012, Opaxio, which is paclitaxel conjugated with poliglumex, an innovative macromolecular taxane created to increase the therapeutic index of paclitaxel, received approval and orphan drug status from the FDA for the treatment of GBM (137). SGT-53 (developed by SynerGene Therapeutics, Inc.) is an anti-transferrin antibody fragment and an example of a targeted nano-drug, which is currently undergoing phase I and II trial testing for GBM treatment (115). Nanotherm uses aminosilane-coated superparamagnetic iron oxide nanoparticles for the induction of local hyperthermia for the treatment of GBM (137). Nanocell is a minicell conjugated with doxorubicin (80). However, its toxicity profile has not been reported and its efficacy has yet to be assessed (80).

Gene therapy. GBM occurs due to the sequential accumulation of genetic alterations (8), making gene therapy a promising alternative to address the limitations of conventional therapy. Therefore, gene or nucleic acid carriers that are able to successfully penetrate into the tumour tissue have been extensively studied. Although several clinical trials have evaluated the use of viral vectors for GBM gene therapy, none achieved FDA approval, mainly due to inefficient viral delivery, lack of tumour penetration and insufficient efficacy $(138,139)$. However, a number of non-viral vectors have shown promising results in pre-clinical trials and have entered clinical trial testing (140). Several gene therapy agents carried by different vectors have been evaluated in clinical trials for GBM treatment.

Herpes simplex virus-thymidine kinase (tk) converts the antiviral drug ganciclovir into ganciclovir triphosphate (141). Its combination with vectors such as retro- or adenoviruses has been investigated in clinical studies, but the results were not promising, due to tumour progression leading to low OS within 10 months of treatment (77\%) (142).

Adenovirus-tk is an adenoviral vector that contains the herpes simplex virus tk gene (143). Its combination with valacyclovir was previously evaluated in a phase I clinical study (12). Although not particularly potent in terms of efficacy, the survival rate was encouraging, prompting the commencement of phase II trial testing, which is currently ongoing $(12,144)$.

Toca 511, a retrovirus vector, is under phase II/III clinical trial examination, and the results were found to be favourable regarding the safety profile and OS of Toca 511 compared with lomustine alone treatment (145). The retroviral replicating vector can permanently integrate the yeast cytosine deaminase gene into the tumour cell genome, thereby converting 5-fluorocytosine into the toxic 5-fluorouracil (146).

Veledimex is an oral activator of human IL-12 that has been shown to increase the survival rate of patients with recurrent GBM in a previous phase I clinical trial (147). A phase I clinical study of Ad-RTS-hIL-12 + Veledimex combined with cemiplimab in patients with recurrent/progressive GBM is currently ongoing (148). 
SGT-53 is a p53 gene transfector that is enclosed in liposomes (149). This active nanoparticle recently underwent phase II clinical evaluation in combination with TMZ for the treatment of recurrent GBM, but the results remain unavailable at present (150).

NU-0129 can transfect small interfering RNAs targeting the $B c l 2 l 12$ oncogene enclosed in spherical nucleic acid gold nanoparticles (151). It recently completed its first human phase 0 clinical trial for GBM treatment (151). In addition to the evidence of crossing the BBB, macrodosing was well-tolerated with no unexpected side effects observed (151).

Viruses. ParvOryx (H-1PV) is an oncolytic virus that specifically targets and destroys tumour cells (152). A previous phase I/II clinical trial revealed that H-1PV is well-tolerated, and can cross the $\mathrm{BBB}$ and enter the tumour to trigger an immune response (44).

Old but new. Currently commercialised for other diseases, several active agents, such as chlorpromazine, chloroquine, metformin or disulfiram, are being investigated for their effects on GBM physiology. Novel chemotherapeutic approaches to GBM treatment have been proposed. However, these processes require additional financial resources and time before marketing (drug development and registration). In this respect, drug re-purposing represents a new option for the pharmaceutical industry. Research efforts to find new uses for drugs originally developed for treating other diseases have been intensified, which is summarised in a number of recent reviews $(24,153-157)$.

Among the most studied repurposing candidates, the following may be mentioned: CNS drugs (chlorpromazine, valproate fananserin, pimozide, trifluoperazine, imipramine, thioridazine and propentofylline); antimalarial drugs (chloroquine and mefloquine); antidiabetics (biguanides-metformin), lonidamine, disulfiram, rapamycin, everolimus, temsirolimus and ridaforolimus (158-160). Due to the heterogeneity that exists within this tumour, this re-purposing strategy may hold great promise for the treatment of GBM.

Instead of monotherapy alone, superior outcomes may also be achieved by combining different types of therapies. Various combinations of therapeutic agents have been studied in previous clinical trials for GBM treatment $(22,161-165)$ and they are summarized in Table III.

\section{Drug therapies under development}

As conventional treatment methods generally cannot prevent recurrence (2), research focus has been shifted onto developing novel strategies to target residual tumour cells, which is essential in GBM therapy (59). Although treatment methods have improved over the last 20 years $(24,96,153-157)$, the OS of patients with GBM has not reached the levels achieved in other types of solid tumours (6). Novel therapy designs are currently developed for clinical trial testing, which are designed to be applied in combination with the current SOC to improve treatment outcomes (59). The novel therapeutic strategies currently under investigation include the following: Molecularly targeted therapies (including the inhibition of growth factor and angiogenic signalling pathways, multi-kinase inhibitors and combinatorial therapy); passive/active immunotherapy (including monoclonal antibodies, cytokine-mediated therapies, adoptive cell transfer, and peptide- or cell-based approaches); stem cell therapy; gene therapy; and precision therapy (Fig. 2). Targeted therapies typically use drugs that inhibit specific signalling pathways (22). A wide variety of drugs that function in this manner are currently under investigation. However, the results have not been satisfactory. In one previous clinical study, the first-generation EGFR inhibitor erlotinib did not confer benefits to GBM treatment due to its unsatisfactory effects, with tumour progression and a median overall survival of 5.7 months $(49,166)$. In addition, negative data were reported by clinical studies that tested rapamycin, an mTOR inhibitor, at different phases of GBM treatment (79). A possible reason for this was that, although the concentrations of rapamycin were sufficient for the in vitro inhibition of mTOR in the tumour, the magnitude of this inhibition inside the tumour cells varied substantially (79). Another difficulty encountered during GBM treatment is the common occurrence of side effects, such as vomiting and nausea, hair loss, headache, fever and weakness (59).

Monoclonal antibodies. One of the leading classes of therapeutics is monoclonal antibodies designed to recognise receptors and ligands expressed on the cell surface (167). They mainly prevent downstream receptor signalling by disrupting receptor-ligand interactions (167).

Bevacizumab is an antibody that targets VEGF and has been approved by the FDA (72). A previous study reported that bevacizumab combined with SOC did not increase the OS compared with SOC alone (168). However, due to limited toxicity compared with SOC, bevacizumab represents one of the leading new treatment methods for GBM (38). AMG595 is another antibody that was recently tested in phase I clinical trials, which specifically targets EGFRvIII (169). AMG595 is an immunoconjugate that cannot be cleaved and consists of a human monoclonal antibody targeting EGFRvIII and mertansine, which is a cytotoxic agent (169). In these trials, AMG595 demonstrated good pharmacokinetic profiles in patients with EGFRvIII-positive GBM (169-171). However, the use of AMG595 remains limited due to increased EGFRvIII mutagenicity (169).

Nimotuzumab is a humanised monoclonal antibody that alters cell division by binding to EGFR (172). A previous phase II trial conducted on patients with high-grade glioma found that, compared with radiation therapy (RT) alone (12.6 months), nimotuzumab and RT improved the median survival time (17.8 months) (173). However, data from another phase III clinical trial on patients with GBM showed no significant changes in the survival time when standard TMZ and RT with or without nimotuzumab was used (174). Additional studies are required to determine whether nimotuzumab can be successfully applied as a front-line therapeutic agent for GBM.

Depatuxizumab mafodotin (ABT-414) is a monoclonal antibody-drug conjugate that binds to EGFR, leading to its inhibition. In addition, ABT-414 is conjugated with the tubulin inhibitor monomethyl auristatin F (175). A recent study on patients with recurrent GBM revealed that depatuxizumab mafodotin treatment resulted in a median survival time of 
Table III. Combined drugs targeting RTKs/mTOR/PI3K signalling in clinical trials of GBM.

\begin{tabular}{|c|c|c|c|}
\hline Drug combination & Clinical trial & Efficiency and drawbacks & (Refs.) \\
\hline Bevacizumab + erlotinib & $\begin{array}{l}\text { Phase II } \\
\text { NCT00671970 }\end{array}$ & $\begin{array}{l}\text { Although bevacizumab + erlotinib was adequately tolerated, } \\
\text { there was no progression-free survival benefit or improved } \\
\text { radiographic response when compared with historical } \\
\text { bevacizumab-salvage therapy }\end{array}$ & $(161)$ \\
\hline Bevacizumab + trebananib & $\begin{array}{l}\text { Phase I/II } \\
\text { NCT01290263 }\end{array}$ & $\begin{array}{l}\text { The study reported serious adverse events, including blood } \\
\text { and lymphatic system disorders, such as decreased platelet } \\
\text { and neutrophil counts }(2.7 \%) \text {, limb edema and fatigue }(2.7 \%) \text {. } \\
\text { There was no significant improvement in outcome compared } \\
\text { with bevacizumab alone }\end{array}$ & $(22)$ \\
\hline Temsirolimus + erlotinib & $\begin{array}{l}\text { Phase I/II } \\
\text { NCT00112736 }\end{array}$ & $\begin{array}{l}\text { The maximum tolerated dosage of temsirolimus + erlotinib } \\
\text { was lower than expected and increased toxicity was observed. } \\
\text { Minimal antitumour activity was noted due to insufficient } \\
\text { tumour drug concentrations }\end{array}$ & $(162)$ \\
\hline Temsirolimus + perifosine & $\begin{array}{l}\text { Phase I/II } \\
\text { NCT01051557 }\end{array}$ & $\begin{array}{l}\text { Serious adverse events, including lung infection, } \\
\text { hyperglycaemia and thromboembolic event were reported, } \\
\text { with a higher risk than temsirolimus alone }\end{array}$ & $(163)$ \\
\hline Sirolimus + erlotinib & $\begin{array}{l}\text { Phase II } \\
\text { NCT00672243 }\end{array}$ & $\begin{array}{l}\text { Limited efficacy among patients with recurrent GBM. The } \\
\text { most frequent toxicities were rash, mucositis, diarrhoea, } \\
\text { fatigue and hyperlipidaemia }\end{array}$ & $(164)$ \\
\hline Sirolimus + vandetanib & $\begin{array}{l}\text { Phase I } \\
\text { NCT00821080 }\end{array}$ & $\begin{array}{l}\text { The combination appeared feasible and safe. } \\
\text { Hypophosphataemia, lymphopenia, rash and fatigue were the } \\
\text { most commonly reported toxicities }\end{array}$ & $(165)$ \\
\hline Pembrolizumab + dactolisib & $\begin{array}{l}\text { Phase IIB } \\
\text { NCT02430363 }\end{array}$ & No results reported & \\
\hline
\end{tabular}

GBM, glioblastoma multiforme; RTK, receptor tyrosin kinase.

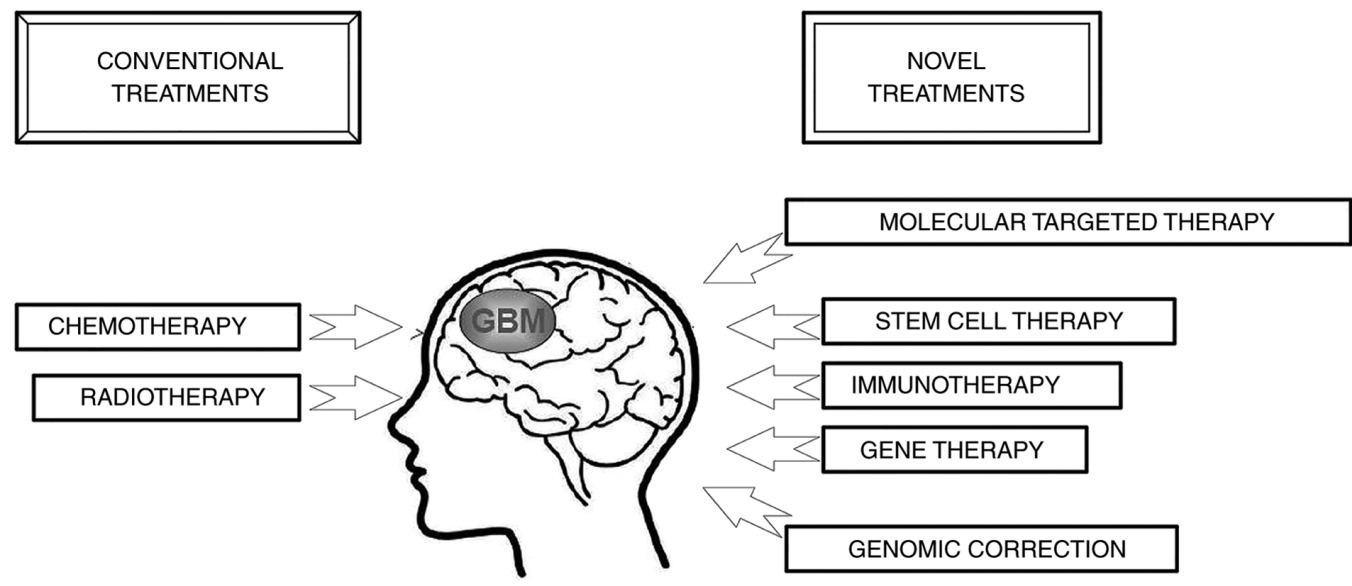

Figure 2. GBM treatment options. GBM, glioblastoma multiforme.

10.7 months (176). At present, only one phase I study has reported the safety and efficacy of ABT-414 when combined with TMZ for recurrent GBM (134).

Targeting stem-like cells in GBM. Stem-like cells were first detected in GBM in 2004 by Singh et al (177), and they were described as cells that are able to initiate tumour growth in vivo. Since malignancy recurrence may be a consequence of the gain of stem cell-like features during disease progression (47), the cancer stem cell phenotype may prove to be an important therapeutic target. An attractive strategy to regulate the GBM stem cell-like properties and progenitor cell phenotype is to target the epigenetic polycomb repressor complex $1 / 2$ and its key drivers enhancer of zeste 2 polycomb repressive complex 2 subunit and BMI1 (178).

Tumouricidal neural stem cell therapy is a promising new strategy which recently entered clinical trial testing in human patients with GBM (46). The therapy consists in tumouricidal 
neural stem cells, which track chemokines to migrate toward solid GBM sites and malignant cells that invade into the healthy areas of the brain (46).

The methods used to identify and target GSCs have not been completely successfully, as the exact mechanisms and functionalities of the putative GSCs markers have not yet been fully elucidated. RNA aptamers that selectively bind to GSCs were previously created on human primary GSCs using cell-systematic evolution of ligand by exponential enrichment methodology (SELEX) (179). Using a cell-SELEX approach, RNA aptamers that selectively bind GSCs were generated. The results proved that they were able to inhibit cell proliferation, migration and stemness, and were able to strongly reduce tumour growth in vivo, proving that this approach is a promising innovative diagnostic and therapeutic tool for GBM (179). Due to the crucial role of GSCs in the recurrence and therapy resistance of GBM, these aptamers represent an innovative drug delivery method and are valuable candidates for the treatment of GBM.

MicroRNAs (miRNAs/miRs). TargoMiR are miR-16-filled micelles that target EGFR and are especially designed to preserve the expression of the miR-15/16 miRNA family, which have been shown to act as tumour suppressors in cancer (180). However, no clinical findings have been reported to date in terms of GBM treatment.

Genomic correction. High-resolution structural genomics has the potential to reveal novel therapeutic options for GBM treatment by integrating structural genomics datasets to identify therapeutic paths in self-renewing cells (181). At $<5 \mathrm{~kb}$ resolution, contact maps allow the identification of individual DNA loops and large-scale genomic compartmentalisation (182). Differences in looping architectures of genes were previously observed among GSCs collected from different patients, suggesting that the $3 \mathrm{D}$ genome architecture may represent a new approach to targeting inter-patient heterogeneity (181).

Other strategies. Other novel investigated strategies for GBM treatment involve medical devices (183). NovoTTF-100A is a medical device that can disrupt cell division by using alternating electric fields (184). In addition, thermal lasers can be used to denature tumour tissues (185). Laser interstitial thermal therapy (NeuroBlate System; LAANTERN) can also destroy tumour cells through heating by using a thermoablative procedure and real-time MRI-guided thermography can be applied (186). In 2018, the FDA approved the treatment of recurrent and newly diagnosed GBM by using medical devices that deliver electric fields directly into the tumour (TTFields; Optune ${ }^{\circledR}$; Novocure GmbH) (187).

Despite advances in the genomic characterisation of GBM, developed targeted drugs have thus far demonstrated insufficient efficacy in clinical trials, with poor patient survival $(22,80,98)$. A large proportion of patients with primary brain tumours typically relapse after standard therapy (20), at which time alternative effective strategies are lacking. To address this issue, research efforts have been directed towards profiling mutations and molecular alterations in the tumours to devise drug treatment regimens that are patient-specific (8). It is hoped that data generated through this profiling can provide the basis for the development of novel and effective therapies.

Over the past decade, studies have been performed in specific cancers to progressively individualise the therapeutic regimens (6). Treatment with custom-designed tyrosine kinase inhibitors or immunotherapeutics have already been used in certain types of cancer, such as haematological malignancies and melanoma (188).

The $\beta$-arrestin family of proteins has been reported to serve an important role in the development of numerous types of cancer (189). However, information regarding its role in gliomas remains poorly understood. Proliferation and response to SOC treatment could be influenced by $\beta-1$ arrestin overexpression (190). As a result, $\beta-1$ arrestin was overexpressed in a HGG cell line through transfection with a $\beta-1$ arrestin plasmid in a previous study (191). Although cells overexpressing $\beta-1$ arrestin exhibited higher susceptibility to TMZ after $24 \mathrm{~h}$, this difference became statistically insignificant compared with that in untransfected cells after 48 and $72 \mathrm{~h}$ (191). This variation in the HGG cell response to identical treatments highlights the importance of individualised therapy (192). Precision medicine is an innovative approach that can be tailored according to the genetic profile of both disease and patient.

A trial that used molecular profiling for guiding individualised treatment plans in patients with recurrent/progressive GBM was initiated in 2014 (trial no. NCT02060890) (193). The aim was to obtain biopsies from patients for extensive genome-wide profiling and to select drugs that may modulate actionable targets such as EGFR, PDGFRA and v-raf murine sarcoma viral oncogene homolog B1 genes (193).

At present, a number of trials on isocitrate dehydrogenase-wild-type GBM are ongoing, in which integrated treatment strategies incorporating single-cell technologies, multi-omics and computational approaches are being studied (194-196).

In terms of drug development, nanomedicine is a relatively new research field. The main objective is to deliver therapeutic agents to the specific targeted sites, preferably in a controlled manner. In this regard, several types of nanoparticles have been studied as potential drug delivery systems carrying bioactive compounds for GBM treatment (197).

However, the specific characteristics of GBM pose major challenges, regardless of the strategy applied. These challenges include cellular heterogeneity, meaning that some drugs cannot penetrate into the tumour tissue efficiently, posing difficulties in biomarker assessment, since repeat on-treatment biopsies are not feasible (198).

\section{Conclusions}

GBM is the most aggressive among all types of primary brain tumours. Currently available SOC therapeutic methods have failed to significantly improve the survival rate, emphasising the need to develop novel therapeutic approaches. Novel biomarker-driven strategies have been developed over the last decades, but they have performed poorly during clinical trial testing. This is mainly due to low BBB permeability and increased resistance/tolerance. Most, if not all, clinical trials tend to test a targeted treatment method using a potential 'one size fits all' approach, but there are several biological differences among individual patients. In recent years, although 
molecular profiling data of tumour tissues are becoming increasingly available, proof-of-concept studies in GBM are still lacking. The biological complexity, lack of data for precision medicine and low efficiency of drug delivery systems are examples of the numerous challenges encountered in the management of GBM that must be addressed.

\section{Acknowledgements}

Not applicable.

\section{Funding}

The present study was funded by Grant PN-II-ID-PCE-3-1041, by the UEFISCDI Authority, Romania.

\section{Availability of data and materials}

Not applicable.

\section{Authors' contributions}

ASS, AC and AD were involved in conceptualisation. $\mathrm{CB}$, SAA, OA and SD were involved in formal analysis. SAA, CB, OA, OS, SD, LGT, VS and ASS prepared the original draft. ASS, LGT, AC and AD reviewed and edited the manuscript. All the authors have read and approved the final manuscript. Data sharing is not applicable.

\section{Ethics approval and consent to participate}

Not applicable.

\section{Patient consent for publication}

Not applicable.

\section{Competing interests}

The authors declare that they have no competing interests.

\section{References}

1. Artene SA, Turcu-Stiolica A, Ciurea ME, Folcuti C, Tataranu LG Alexandru O, Purcaru OS, Tache DE, Boldeanu MV, Silosi C and Dricu A: Comparative effect of immunotherapy and standard therapy in patients with high grade glioma: A meta-analysis of published clinical trials. Sci Rep 8: 11800, 2018.

2. van Elsas MJ, van Hall T and van der Burg SH: Future challenges in cancer resistance to immunotherapy. Cancers (Basel) 12: 935, 2020

3. Oprita A and Sevastre AS: New pharmaceutical dosage forms used in the treatment of breast cancer. Polymeric micelles Medico Oncol 1: 38-52, 2020.

4. Sevastre AS, Baloi SC, Cioc CE and Oprita A: New pharmaceutical dosage forms used in the treatment of breast cancer. Liposomes. Medico Oncol 2: 10-24, 2021.

5. Cosaceanu D, Carapancea M, Alexandru O, Budiu R Martinsson HS, Starborg M, Vrabete M, Kanter L, Lewensohn R and Dricu A: Comparison of three approaches for inhibiting insulin-like growth factor I receptor and their effects on NSCLC cell lines in vitro. Growth Factors 25: 1-8, 2007.

6. Ostrom QT, Gittleman H, Fulop J, Liu M, Blanda R, Kromer C, Wolinsky Y, Kruchko C and Barnholtz-Sloan JS: CBTRUS statistical report: Primary brain and central nervous system tumors diagnosed in the United States in 2008-2012. Neuro Oncol 17 (Suppl 4): iv1-iv62, 2015.
7. Kleihues $\mathrm{P}$ and Cavenee W: Tumours of the nervous system: World Health Organization classification of tumours. IARC Press, Lyon, 2000.

8. Brennan CW, Verhaak RG, McKenna A, Campos B Noushmehr H, Salama SR, Zheng S, Chakravarty D, Sanborn JZ, Berman SH, et al: The somatic genomic landscape of glioblastoma. Cell 155: 462-477, 2013.

9. Zhang J, Stevens MF and Bradshaw TD: Temozolomide: Mechanisms of action, repair and resistance. Curr Mol Pharmacol 5: 102-114, 2012.

10. Stupp R, Mason WP, van den Bent MJ, Weller M, Fisher B, Taphoorn MJ, Belanger K, Brandes AA, Marosi C, Bogdahn U, et al: Radiotherapy plus concomitant and adjuvant temozolomide for glioblastoma. N Engl J Med 352: 987-996, 2005.

11. Westphal M, Hilt DC, Bortey E, Delavault P, Olivares R, Warnke PC, Whittle IR, Jääskeläinen J and Ram Z: A phase 3 trial of local chemotherapy with biodegradable carmustine (BCNU) wafers (Gliadel wafers) in patients with primary malignant glioma. Neuro Oncol 5: 79-88, 2003.

12. Chiocca EA, Aguilar LK, Bell SD, Kaur B, Hardcastle J, Cavaliere R, McGregor J, Lo S, Ray-Chaudhuri A, Chakravarti A, et al: Phase IB study of gene-mediated cytotoxic immunotherapy adjuvant to up-front surgery and intensive timing radiation for malignant glioma. J Clin Oncol 29: 3611-3619, 2011

13. Vollmann-Zwerenz A, Leidgens V, Feliciello G, Klein CA and Hau P: Tumor cell invasion in glioblastoma. Int J Mol Sci 21: 1932, 2020.

14. Fernandes C, Costa A, Osório L, Lago RC, Linhares P, Carvalho B and Caeiro C: Current standards of care in glioblastoma therapy. In: Glioblastoma. De Vleeschouwer S (ed). Codon Publications, Brisbane, AU, Chapter 11, 2017.

15. Lee SY: Temozolomide resistance in glioblastoma multiforme. Genes Dis 3: 198-210, 2016.

16. Alves AL, Gomes IN, Carloni AC, Rosa MN, da Silva LS, Evangelista AF, Reis RM and Silva VA: Role of glioblastoma stem cells in cancer therapeutic resistance: A perspective on antineoplastic agents from natural sources and chemical derivatives. Stem Cell Res Ther 12: 206, 2021.

17. Fleurence J, Bahri M, Fougeray S, Faraj S, Vermeulen S, Pinault E, Geraldo F, Oliver L, Véziers J, Marquet $\mathrm{P}$, et al: Impairing temozolomide resistance driven by glioma stem-like cells with adjuvant immunotherapy targeting $\mathrm{O}$-acetyl GD2 ganglioside. Int J Cancer 146: 424-438, 2020.

18. Horescu C, Elena Cioc C, Tuta C, Sevastre AS, Tache DE, Alexandru O, Artene SA, Danoiu S, Dricu A and Stefana Oana P: The effect of temozolomide in combination with doxorubicin in glioblastoma cells in vitro. J Immunoassay Immunochem 41: 1033-1043, 2020.

19. Lee EQ, Reardon DA, Schiff D, Drappatz J, Muzikansky A, Grimm SA, Norden AD, Nayak L, Beroukhim R, Rinne ML, et al: Panobinostat in combination with bevacizumab for recurrent glioblastoma and anaplastic glioma. J Clin Oncol 32: (Suppl 15): S2020, 2014.

20. Herrlinger U, Tzaridis T, Mack F, Steinbach JP, Schlegel U, Sabel M, Hau P, Kortmann RD, Krex D, Grauer O, et al: Lomustine-temozolomide combination therapy versus standard temozolomide therapy in patients with newly diagnosed glioblastoma with methylated MGMT promoter (CeTeG/NOA-09): A randomised, open-label, phase 3 trial. Lancet 393: 678-688, 2019.

21. Parrozzani R, Lombardi G, Midena E, Londei D, Padovan M, Marchione G, Caccese M, Midena G, Zagonel V and Frizziero L: Ocular side effects of EGFR-inhibitor ABT-414 in recurrent glioblastoma: A long-term safety study. Front Oncol 10: 593461, 2020.

22. Cruz Da Silva E, Mercier MC, Etienne-Selloum N, Dontenwill M and Choulier L: A systematic review of glioblastoma-targeted therapies in phases II, III, IV clinical trials. Cancers (Basel) 13: $1795,2021$.

23. Brown TJ, Brennan MC, Li M, Church EW, Brandmeir NJ, Rakszawski KL, Patel AS, Rizk EB, Suki D, Sawaya R and Glantz M: Association of the extent of resection with survival in glioblastoma: A systematic review and meta-analysis. JAMA Oncol 2: 1460-1469, 2016.

24. Alexandru O, Horescu C, Sevastre AS, Cioc CE, Baloi C, Oprita A and Dricu A: Receptor tyrosine kinase targeting in glioblastoma: Performance, limitations and future approaches. Contemp Oncol (Pozn) 24: 55-66, 2020.

25. Kleinberg L: Polifeprosan 20,3.85\% carmustine slow release wafer in malignant glioma: Patient selection and perspectives on a low-burden therapy. Patient Prefer Adherence 10: 2397-2406, 2016. 
26. Thirupathy A, Srinivas P, Babu DS and Mamidi S: Formulation and evaluation of sustained release implantable microspheres of temozolomide for brain targeting prepared by a novel technique. Int J Pharm Pharm Sci 3: 187-194, 2011

27. Lam FC, Morton SW, Wyckoff J, Vu Han TL, Hwang MK, Maffa A, Balkanska-Sinclair E, Yaffe MB, Floyd SR and Hammond PT: Enhanced efficacy of combined temozolomide and bromodomain inhibitor therapy for gliomas using targeted nanoparticles. Nat Commun 9: 1991, 2018.

28. Fang C, Wang K, Stephen ZR, Mu Q, Kievit FM, Chiu DT, Press OW and Zhang M: Temozolomide nanoparticles for targeted glioblastoma therapy. ACS Appl Mater Interfaces 7: 6674-6682, 2015.

29. Ramalho MJ, Sevin E, Gosselet F, Lima J, Coelho MAN, Loureiro JA and Pereira MC: Receptor-mediated PLGA nanoparticles for glioblastoma multiforme treatment. Int J Pharm 545: 84-92, 2018.

30. Bertucci A, Prasetyanto EA, Septiadi D, Manicardi A, Brognara E, Gambari R, Corradini R and De Cola L: Combined delivery of temozolomide and anti-miR221 PNA using mesoporous silica nanoparticles induces apoptosis in resistant glioma Cells. Small 11: 5687-5695, 2015.

31. Irani M, Mir Mohamad Sadeghi G and Haririan I: A novel biocompatible drug delivery system of chitosan/temozolomide nanoparticles loaded PCL-PU nanofibers for sustained delivery of temozolomide. Int J Biol Macromol 97: 744-751, 2017.

32. Gürten B, Yenigül E, Sezer AD, Altan C and Malta S: Targeting of temozolomide using magnetic nanobeads: An in vitro study. Braz J Pharm Sci 56, 2020.

33. Chakravarty M, Ganguli P, Murahari M, Sarkar RR, Peters GJ and Mayur YC: Study of combinatorial drug synergy of novel acridone derivatives with temozolomide using in-silico and in-vitro methods in the treatment of drug-resistant glioma. Front Oncol 11: 625899, 2021.

34. Artene SA, Tuţă C, Dragoi A, Alexandru O, Stefana Oana P, Tache DE, Dănciulescu MM, Boldeanu MV, Silosi CA and Dricu A: Current and emerging EGFR therapies for glioblastoma. J Immunoassay Immunochem 39: 1-11, 2018.

35. Alexandru O, Purcaru SO, Tataranu LG, Lucan L, Castro J, Folcuţi C, Artene SA, Tuţă C and Dricu A: The influence of EGFR inactivation on the radiation response in high grade glioma. Int $\mathrm{J}$ Mol Sci 19: 229, 2018

36. Ameratunga M, Pavlakis N, Wheeler H, Grant R, Simes J and Khasraw M: Anti-angiogenic therapy for high-grade glioma. Cochrane Database Syst Rev 11: CD008218, 2018.

37. Dietrich J, Wang D and Batchelor TT: Cediranib: Profile of a novel anti-angiogenic agent in patients with glioblastoma. Expert Opin Investig Drugs 18: 1549-1557, 2009.

38. Hyman DM, Rizvi N, Natale R, Armstrong DK, Birrer M, Recht L, Dotan E, Makker V, Kaley T, Kuruvilla D, et al: Phase I study of MEDI3617, a selective angiopoietin-2 inhibitor alone and combined with carboplatin/paclitaxel, paclitaxel, or bevacizumab for advanced solid tumors. Clin Cancer Res 24 2749-2757, 2018

39. Lin F, de Gooijer MC, Hanekamp D, Chandrasekaran G, Buil LC, Thota N, Sparidans RW, Beijnen JH, Würdinger T and van Tellingen O: PI3K-mTOR pathway inhibition exhibits efficacy against high-grade glioma in clinically relevant mouse models Clin Cancer Res 23: 1286-1298, 2017.

40. Popescu AM, Alexandru O, Brindusa C, Purcaru SO, Tache DE, Tataranu LG, Taisescu C and Dricu A: Targeting the VEGF and PDGF signaling pathway in glioblastoma treatment. Int J Clin Exp Pathol 8: 7825-7837, 2015.

41. Purcaru SO, Tache DE, Serban F, Folcuti RM, Georgescu AM, Stovicek PO, Danciulescu MM, Tataranu LG and Dricu A: Effect of VEGFR, PDGFR and PI3K/mTOR targeting in glioblastoma. Curr Health Sci J 41: 325-332, 2015.

42. Schijns VE, Pretto C, Devillers L, Pierre D, Hofman FM, Chen TC, Mespouille P, Hantos P, Glorieux P, Bota DA and Stathopoulos A: First clinical results of a personalized immunotherapeutic vaccine against recurrent, incompletely resected, treatment-resistant glioblastoma multiforme (GBM) tumors, based on combined allo- and auto-immune tumor reactivity. Vaccine 33: 2690-2696, 2015.

43. Wahl LM and Pattenden T: Prophage provide a safe haven for adaptive exploration in temperate viruses. Genetics 206: 407-416, 2017

44. Geletneky K, Hajda J, Angelova A, Leuchs B, Capper D Bartsch AJ, Neumann JO, Schöning T, Hüsing J, Beelte B, et al: Oncolytic $\mathrm{H}-1$ parvovirus shows safety and signs of immunogenic activity in a first phase I/IIa glioblastoma trial. Mol Ther 25 . $2620,2017$.
45. Vatu BI, Artene SA, Staicu AG, Turcu-Stiolica A, Folcuti C, Dragoi A, Cioc C, Baloi SC, Tataranu LG, Silosi C and Dricu A: Assessment of efficacy of dendritic cell therapy and viral therapy in high grade glioma clinical trials. A meta-analytic review. J Immunoassay Immunochem 40: 70-80, 2019.

46. Satterlee AB, Dunn DE, Lo DC, Khagi S and Hingtgen S: Tumoricidal stem cell therapy enables killing in novel hybrid models of heterogeneous glioblastoma. Neuro Oncol 21: $1552-1564,2019$

47. Ciurea ME, Georgescu AM, Purcaru SO, Artene SA, Emami GH, Boldeanu MV, Tache DE and Dricu A: Cancer stem cells: Biological functions and therapeutically targeting. Int J Mol Sci 15: 8169-8185, 2014

48. Cancer Genome Atlas Research Network: Comprehensive genomic characterization defines human glioblastoma genes and core pathways. Nature 455: 1061-1068, 2008

49. Liu S, Tang Y, Yuan X, Yuan D, Liu J, Li B and Li Y: Inhibition of $\mathrm{Rb}$ and $\mathrm{mTOR}$ signaling associates with synergistic anticancer effect of palbociclib and erlotinib in glioblastoma cells. Invest New Drugs 36: 961-969, 2018.

50. Forte IM, Indovina P, Iannuzzi CA, Cirillo D, Di Marzo D, Barone D, Capone F, Pentimalli F and Giordano A: Targeted therapy based on p53 reactivation reduces both glioblastoma cell growth and resistance to temozolomide. Int $\mathrm{J}$ Oncol 54: 2189-2199, 2019

51. Raizer JJ, Giglio P, Hu J, Groves M, Merrell R, Conrad C, Phuphanich S, Puduvalli VK, Loghin M, Paleologos N, et al: A phase II study of bevacizumab and erlotinib after radiation and temozolomide in MGMT unmethylated GBM patients. J Neurooncol 126: 185-192, 2016.

52. Piao Y, Park SY, Henry V, Smith BD, Tiao N, Flynn DL and de Groot JF: Novel MET/TIE2/VEGFR2 inhibitor altiratinib inhibits tumor growth and invasiveness in bevacizumab-resistant glioblastoma mouse models. Neuro Oncol 18: 1230-1241, 2016.

53. Payton M, Jun T, Wayne W, Yu D, Manoukian R, Chung G, Zhang N, Sun JR, Kaplan-Lefko P, Scully S, et al: Antagonism of Ang-Tie2 and Dll4-Notch signaling has opposing effects on tumor endothelial cell proliferation, evidenced by a new flow cytometry method. Lab Invest 94: 1296-1308, 2014.

54. Wick W, Puduvalli VK, Chamberlain MC, van den Bent MJ, Carpentier AF, Cher LM, Mason W, Weller M, Hong S, Musib L, et al: Phase III study of enzastaurin compared with lomustine in the treatment of recurrent intracranial glioblastoma. J Clin Oncol 28: 1168-1174, 2010.

55. Wen PY, Cloughesy TF, Olivero AG, Morrissey KM, Wilson TR, Lu X, Mueller LU, Coimbra AF, Ellingson BM, Gerstner E, et al: First-in-human phase I study to evaluate the brain-penetrant $\mathrm{PI} 3 \mathrm{~K} / \mathrm{mTOR}$ inhibitor GDC-0084 in patients with progressive or recurrent high-grade glioma. Clin Cancer Res 26: 1820-1828, 2020.

56. Maklad A, Sharma A and Azimi I: Calcium signaling in brain cancers: Roles and therapeutic targeting. Cancers (Basel) 11: 145, 2019.

57. Solca F, Dahl G, Zoephel A, Bader G, Sanderson M, Klein C, Kraemer O, Himmelsbach F, Haaksma E and Adolf GR: Target binding properties and cellular activity of afatinib (BIBW 2992), an irreversible ErbB family blocker. J Pharmacol Exp Ther 343: 342-350, 2012.

58. Dermawan JK, Hitomi M, Silver DJ, Wu Q, Sandlesh P, Sloan AE, Purmal AA, Gurova KV, Rich JN, Lathia JD, et al: Pharmacological targeting of the histone chaperone complex FACT preferentially eliminates glioblastoma stem cells and prolongs survival in preclinical models. Cancer Res 76: 2432-2442, 2016.

59. Stylli SS: Novel treatment strategies for glioblastoma. Cancers (Basel) 12: 2883, 2020.

60. Bloch O, Lim M, Sughrue ME, Komotar RJ, Abrahams JM, O'Rourke DM, D'Ambrosio A, Bruce JN and Parsa AT: Autologous heat shock protein peptide vaccination for newly diagnosed glioblastoma: impact of peripheral PD-L1 expression on response to therapy. Clin Cancer Res 23: 3575-3584, 2017.

61. Krendyukov A and Gieffers C: Asunercept as an innovative therapeutic approach for recurrent glioblastoma and other malignancies. Cancer Manag Res 11: 8095-8100, 2019.

62. von Achenbach C, Silginer M, Blot V, Weiss WA and Weller M: Depatuxizumab mafodotin (ABT-414)-induced glioblastoma cell death requires EGFR overexpression, but not $\mathrm{EGFR}^{\mathrm{Y} 1068}$ phosphorylation. Mol Cancer Ther 19: 1328-1339, 2020. 
63. Lukas RV, Juhász C, Wainwright DA, James CD, Kennedy E, Stupp R and Lesniak MS: Imaging tryptophan uptake with positron emission tomography in glioblastoma patients treated with indoximod. J Neurooncol 141: 111-120, 2019.

64. Angelova AL, Barf M, Geletneky K, Unterberg A and Rommelaere J: Immunotherapeutic potential of oncolytic H-1 parvovirus: Hints of glioblastoma microenvironment conversion towards immunogenicity. Viruses 15: 382, 2017.

65. Alphandéry E: Glioblastoma treatments: An account of recent industrial developments. Front Pharmacol 9: 879, 2018.

66. Łata S and Molczyk A: Side effects of temozolomide treatment in patient with glioblastoma multiforme-case study. Przegl Lek 67: 445-446, 2010 (In Polish).

67. Sabel M and Giese A: Safety profile of carmustine wafers in malignant glioma: A review of controlled trials and a decade of clinical experience. Curr Med Res Opin 24: 3239-3257, 2008.

68. Wick W, Gorlia T, Bendszus M, Taphoorn M, Sahm F, Harting I Brandes AA, Taal W, Domont J, Idbaih A, et al: Lomustine and bevacizumab in progressive glioblastoma. N Engl J Med 377: 1954-1963, 2017

69. Holdhoff M, Ye X, Supko JG, Nabors LB, Desai AS, Walbert T, Lesser GJ, Read WL, Lieberman FS, Lodge MA, et al: Timed sequential therapy of the selective T-type calcium channel blocker mibefradil and temozolomide in patients with recurrent high-grade gliomas. Neuro Oncol 19: 845-852, 2017.

70. Alshami J, Guiot MC, Owen S, Kavan P, Gibson N, Solca F, Cseh A, Reardon DA and Muanza T: Afatinib, an irreversible ErbB family blocker, with protracted temozolomide in recurrent glioblastoma: A case report. Oncotarget 6: 34030-34037, 2015

71. Clinical Trials: National Library of Medicine: Safety Study of VAL-083 in patients with recurrent malignant glioma. Available from: https://clinicaltrials.gov/ct2/show/NCT01478178. Accessed August 5,2021.

72. Mamo A, Baig A, Azam M, Rho YS, Sahebjam S, Muanza T, Owen S, Petrecca K, Guiot MC, Al-Shami J, et al: Progression pattern and adverse events with bevacizumab in glioblastoma. Curr Oncol 23: e468-e471, 2016

73. Odia Y, Sul J, Shih JH, Kreisl TN, Butman JA, Iwamoto FM and Fine HA: A Phase II trial of tandutinib (MLN 518) in combination with bevacizumab for patients with recurrent glioblastoma. CNS Oncol 5: 59-67, 2016.

74. Swartz AM, Li QJ and Sampson JH: Rindopepimut: A promising immunotherapeutic for the treatment of glioblastoma multiforme. Immunotherapy 6: 679-690, 2014.

75. Fenstermaker RA, Ciesielski MJ, Qiu J, Yang N, Frank CL, Lee KP, Mechtler LR, Belal A, Ahluwalia MS and Hutson AD: Clinical study of a survivin long peptide vaccine (SurVaxM) in patients with recurrent malignant glioma. Cancer Immunol Immunother 65: 1339-1352, 2016.

76. Rampling R, Peoples S, Mulholland PJ, James A, Al-Salihi O, Twelves CJ, McBain C, Jefferies S, Jackson A, Stewart W, et al: A cancer research UK first time in human phase I trial of IMA950 (novel multipeptide therapeutic vaccine) in patients with newly diagnosed glioblastoma. Clin Cancer Res 22: 4776-4785, 2016.

77. Wen PY, Reardon DA, Armstrong TS, Phuphanich S, Aiken RD, Landolfi JC, Curry WT, Zhu JJ, Glantz M, Peereboom DM, et al: A randomized double-blind placebo-controlled phase II trial of dendritic cell vaccine ICT-107 in newly diagnosed patients with glioblastoma. Clin Cancer Res 25: 5799-5807, 2019.

78. Liau LM, Ashkan K, Tran DD, Campian JL, Trusheim JE, Cobbs CS, Heth JA, Salacz M, Taylor S, D'Andre SD, et al: First results on survival from a large Phase 3 clinical trial of an autologous dendritic cell vaccine in newly diagnosed glioblastoma. J Transl Med 16: 142, 2018

79. Cloughesy TF, Yoshimoto K, Nghiemphu P, Brown K, Dang J, Zhu S, Hsueh T, Chen Y, Wang W, Youngkin D, et al: Antitumor activity of rapamycin in a Phase I trial for patients with recurrent PTEN-deficient glioblastoma. PLoS Med 5: e8, 2008.

80. Whittle JR, Lickliter JD, Gan HK, Scott AM, Simes J, Solomon BJ, MacDiarmid JA, Brahmbhatt $\mathrm{H}$ and Rosenthal MA: First in human nanotechnology doxorubicin delivery system to target epidermal growth factor receptors in recurrent glioblastoma. J Clin Neurosci 22: 1889-1894, 2015.

81. Philbrick BD and Adamson DC: Early clinical trials of Toca 511 and Toca FC show a promising novel treatment for recurrent malignant glioma. Expert Opin Investig Drugs 28: 207-216, 2019.

82. Chiocca EA, Yu J, Lukas RV, Buck J, Demars N, Barrett J, Yang Y, Cooper L and Lebel F: ATIM-26. A phase 1 study of AD-RTS-HIL-12 + veledimex in adult recurrent glioblastoma. Neuro Oncol 19 (Suppl 6): vi32, 2017.
83.Zuccarini M, Giuliani P, Ziberi S, Carluccio M, Iorio PD, Caciagli $\mathrm{F}$ and Ciccarelli $\mathrm{R}$ : The role of Wnt signal in glioblastoma development and progression: A possible new pharmacological target for the therapy of this tumor. Genes (Basel) 9: 105, 2018.

84. Peñaranda-Fajardo NM, Meijer C, Liang Y, Dijkstra BM, Aguirre-Gamboa R, den Dunnen WFA and Kruyt FAE: ER stress and UPR activation in glioblastoma: Identification of a noncanonical PERK mechanism regulating GBM stem cells through SOX2 modulation. Cell Death Dis 10: 690, 2019.

85. European Medicines Agency: COVID-19 pandemic. Available from: www.ema.europa.eu. Accessed September 5, 2021.

86. Günther W, Pawlak E, Damasceno R, Arnold H and Terzis AJ: Temozolomide induces apoptosis and senescence in glioma cells cultured as multicellular spheroids. Br J Cancer 88: 463-469, 2003.

87. Darlix A, Baumann C, Lorgis V, Ghiringhelli F, Blonski M, Chauffert B, Zouaoui S, Pinelli C, Rech F, Beauchesne P and Taillandier L: Prolonged administration of adjuvant temozolomide improves survival in adult patients with glioblastoma. Anticancer Res 33: 3467-3474, 2013.

88. Nonnenmacher L, Westhoff MA, Fulda S, Karpel-Massler G, Halatsch ME, Engelke J, Simmet T, Corbacioglu S and Debatin KM: RIST: A potent new combination therapy for glioblastoma. Int J Cancer 136: E173-E187, 2015.

89. Halatsch ME, Kast RE, Dwucet A, Hlavac M, Heiland T, Westhoff MA, Debatin KM, Wirtz CR, Siegelin MD and Karpel-Massler G: Bcl-2/Bcl-xL inhibition predominantly synergistically enhances the anti-neoplastic activity of a low-dose CUSP9 repurposed drug regime against glioblastoma. Br J Pharmacol 176: 3681-3694, 2019.

90. Affronti ML, Heery CR, Herndon JE II, Rich JN, Reardon DA, Desjardins A, Vredenburgh JJ, Friedman AH, Bigner DD and Friedman HS: Overall survival of newly diagnosed glioblastoma patients receiving carmustine wafers followed by radiation and concurrent temozolomide plus rotational multiagent chemotherapy. Cancer 115: 3501-3511, 2009.

91. Clinical Trials: National Library of Medicine: O6-benzylguaninemediated tumor sensitization with chemoprotected autologous stem cell in treating patients with malignant gliomas. Available from: https://clinicaltrials.gov/ct2/show/NCT00669669? term $=$ carmustine $\&$ recrs $=\mathrm{d} \&$ cond $=$ glioblastoma $\&$ draw $=2 \&$ rank $=1$. Accessed February 25, 2021

92. National Library of Medicine: National Center for Biotechnology Information: Lomustine. Available from: https://pubchem.ncbi. nlm.nih.gov/compound/Lomustine. Accessed February 25, 2021.

93. Reimunde P, Pensado-López A, Carreira Crende M, Lombao Iglesias V, Sánchez L, Torrecilla-Parra M, Ramírez CM, Anfray C and Torres Andón F: Cellular and molecular mechanisms underlying glioblastoma and zebrafish models for the discovery of new treatments. Cancers (Basel) 13: 1087, 2021

94. Reardon DA, Nabors LB, Mason WP, Perry JR, Shapiro W, Kavan P, Mathieu D, Phuphanich S, Cseh A, Fu Y, et al: Phase I/randomized phase II study of afatinib, an irreversible ErbB family blocker, with or without protracted temozolomide in adults with recurrent glioblastoma. Neuro Oncol 17: 430-439, 2015.

95. Vengoji R, Macha MA, Nimmakayala RK, Rachagani S, Siddiqui JA, Mallya K, Gorantla S, Jain M, Ponnusamy MP, Batra SK and Shonka N: Afatinib and temozolomide combination inhibits tumorigenesis by targeting EGFRvIII-cMet signaling in glioblastoma cells. J ExpClin Cancer Res 38: 266, 2019.

96. Oprita A, Baloi SC, Staicu GA, Alexandru O, Tache DE, Danoiu S, Micu ES and Sevastre AS: Updated insights on EGFR signaling pathways in glioma. Int J Mol Sci 22: 587, 2021.

97. Clinical Trials: National Library of Medicine. Available from: https://clinicaltrials.gov/. Accessed April 5, 2021.

98. Lassman AB, Pugh SL, Gilbert MR, Aldape KD, Geinoz S, Beumer JH, Christner SM, Komaki R, DeAngelis LM, Gaur R, et al: Phase 2 trial of dasatinib in target-selected patients with recurrent glioblastoma (RTOG 0627). Neuro Oncol 17: 992-998, 2015

99. Lombardi G, De Salvo GL, Brandes AA, Eoli M, Rudà R, Faedi M, Lolli I, Pace A, Daniele B, Pasqualetti F, et al: Regorafenib compared with lomustine in patients with relapsed glioblastoma (REGOMA): A multicentre, open-label, randomised, controlled, phase 2 trial. Lancet Oncol 20: 110-119, 2019.

100. Stehman FB, Blom J, Blessing JA, Ehrlich CE and Mangan C: Phase II trial of galactitol 1,2:5,6-dianhydro (NSC 132313) in the treatment of advanced gynecologic malignancies: A gynecologic oncology group study. Gynecol Oncol 15: 381-390, 1983 . 
101. O'Brien B, Groot J, Kamiya-Matsuoka C, Weathers SP, Bacha J, Brown D, Steino A, Langlands J, Schwartz R, Kanekal S, et al: ACTR-27. Phase 2 study of dianhydrogalactitol (val-083) in patients with MGMT-unmethylated, bevacizumab-naïve recurrent glioblastoma. Neuro Oncol 20 (Suppl 6): vi17, 2018

102. Keir ST, Friedman HS, Reardon DA, Bigner DD and Gray LA Mibefradil, a novel therapy for glioblastoma multiforme: Cell cycle synchronization and interlaced therapy in a murine model. J Neurooncol 111: 97-102, 2013.

103. Lester-Coll NH, Supko JG, Kluytenaar J, Pavlik KF, Yu JB, Moliterno J, Piepmeier J, Becker K, Baehring JM, Huttner A, et al: Mibefradil dihydrochoride with hypofractionated radiation for recurrent glioblastoma: A phase I dose expansion trial. J Clin Oncol 36 (Suppl 15): e14046, 2018.

104. Clinical Trials: National Library of Medicine. Available from: https://clinicaltrials.gov/ct2/results?cond=glioblastoma\&term= mibefradil $\&$ cntry $=\&$ state $=\&$ city $=\&$ dist $=$. Accessed February 20 , 2021.

105. Wang N, Jain RK and Batchelor TT: New Directions in anti-angiogenic therapy for glioblastoma. Neurotherapeutics 14 : 321-332, 2017

106. Arbab AS: Activation of alternative pathways of angiogenesis and involvement of stem cells following anti-angiogenesis treatment in glioma. Histol Histopathol 27: 549-557, 2012.

107. Friedman HS, Prados MD, Wen PY, Mikkelsen T, Schiff D Abrey LE, Yung WK, Paleologos N, Nicholas MK, Jensen R, et al: Bevacizumab alone and in combination with irinotecan in recurrent glioblastoma. J Clin Oncol 27: 4733-4740, 2009.

108. Lu G, Rao M, Zhu P, Liang B, El-Nazer RT, Fonkem E, Bhattacharjee MB and Zhu JJ: Triple-drug therapy with bevacizumab, irinotecan, and temozolomide plus tumor treating fields for recurrent glioblastoma: A retrospective study. Front Neurol 10: 42, 2019.

109. Galanis E, Anderson SK, Twohy EL, Carrero XW, Dixon JG, Tran DD, Jeyapalan SA, Anderson DM, Kaufmann TJ, Feathers RW, et al: A phase 1 and randomized, placebo-controlled phase 2 trial of bevacizumab plus dasatinib in patients with recurrent glioblastoma: Alliance/north central cancer treatment group N0872. Cancer 125: 3790-3800, 2019.

110. Akiyode O and Dunkelly-Allen N: Ranibizumab: A review of its use in the treatment of diabetic retinopathy in patients with diabetic macular edema. J Pharm Technol 32: 22-28, 2016

111. Batchelor TT, Gerstner ER, Ye X, Desideri S, Duda DG, Peereboom D, Lesser GJ, Chowdhary S, Wen PY, Grossman S and Supko JG: Feasibility, phase I, and phase II studies of tandutinib, an oral platelet-derived growth factor receptor- $\beta$ tyrosine kinase inhibitor, in patients with recurrent glioblastoma. Neuro Oncol 19: 567-575, 2017.

112. Batchelor TT, Mulholland P, Neyns B, Nabors LB, Campone M, Wick A, Mason W, Mikkelsen T, Phuphanich S, Ashby LS, et al: Phase III randomized trial comparing the efficacy of cediranib as monotherapy, and in combination with lomustine, versus lomustine alone in patients with recurrent glioblastoma. J Clin Oncol 31: 3212-3218, 2013.

113. Batchelor TT, Gerstner ER, Emblem KE, Duda DG, Kalpathy-Cramer J, Snuderl M, Ancukiewicz M, Polaskova P, Pinho MC, Jennings D, et al: Improved tumor oxygenation and survival in glioblastoma patients who show increased blood perfusion after cediranib and chemoradiation. Proc Natl Acad Sci USA 110: 19059-19064, 2013

114. Odia Y, Iwamoto FM, Moustakas A, Fraum TJ, Salgado SA, Li A Kreisl TN, Sul J, Butman JA and Fine HA: A phase II trial of enzastaurin (LY317615) in combination with bevacizumab in adults with recurrent malignant gliomas. J Neuro Oncol 127: 127-135, 2016.

115. Clinical Trials: A Trial of enzastaurin plus temozolomide during and following radiation therapy in patients with newly diagnosed glioblastoma with or without the novel genomic biomarker, DGM1. Available from: https://clinicaltrials. gov/ct2/show/NCT03776071. Accessed January 15, 2021.

116. Limeta A, Ji B,Levin M, Gatto F and Nielsen J: Meta-analysis of the gut microbiota in predicting response to cancer immunotherapy in metastatic melanoma. JCI Insight 5: e140940, 2020

117. Conforti F, Pala L, Bagnardi V, De Pas T, Martinetti M, Viale G, Gelber RD and Goldhirsch A: Cancer immunotherapy efficacy and patients' sex: A systematic review and meta-analysis. Lancet Oncol 19: 737-746, 2018

118. Tarantino P, Gandini S, Trapani D, Criscitiello C and Curigliano G: Immunotherapy addition to neoadjuvant chemotherapy for early triple negative breast cancer: A systematic review and meta-analysis of randomized clinical trials. Crit Rev Oncol Hematol 159: 103223, 2021.
119. Reardon DA, Omuro A, Brandes AA, Rieger J, Wick A Sepulveda J, Phuphanich S, de Souza P, Ahluwalia MS, Lim M, et al: Os10.3 randomized phase 3 study evaluating the efficacy and safety of nivolumab vs bevacizumab in patients with recurrent glioblastoma: Checkmate 143. Neuro Oncol 19 (Suppl 3): iii21, 2017.

120. Clinical Trials: National Library of Medicine: Available from: https://clinicaltrials.gov/ct2/results?cond=Glioblastoma $\&$ term $=$ immunotherapy $\&$ cntry $=\&$ state $=\&$ cit $y=\&$ dist $=$. Accessed September 3, 2021.

121. Cuzzubbo S, Javeri F, Tissier M, Roumi A, Barlog C, Doridam J, Lebbe C, Belin C, Ursu R and Carpentier AF: Neurological adverse events associated with immune checkpoint inhibitors: Review of the literature. Eur J Cancer 73: 1-8, 2017.

122. Weller M, Butowski N, Tran DD, Recht LD, Lim M, Hirte H, Ashby L, Mechtler L, Goldlust SA, Iwamoto F, et al: Rindopepimut with temozolomide for patients with newly diagnosed, EGFRvIII-expressing glioblastoma (ACT IV): A randomised, double-blind, international phase 3 trial. Lancet Oncol 18: 1373-1385, 2017.

123. Schuster J, Lai RK, Recht LD, Reardon DA, Paleologos NA, Groves MD, Mrugala MM, Jensen R, Baehring JM, Sloan A, et al: A phase II, multicenter trial of rindopepimut (CDX-110) in newly diagnosed glioblastoma: the ACT III study. Neuro Oncol 17: 854-861, 2015

124. Wood CG and Mulders P: Vitespen: A preclinical and clinical review. Future Oncol 5: 763-774, 2009.

125. Clinical Trials: Study of Pembrolizumab Plus SurVaxM for Glioblastoma at First Recurrence. Available from: https://clinicaltrials.gov/ct2/show/NCT04013672?term $=$ SurVaxM\&cond $=\mathrm{g}$ lioblastoma\&draw=2\&rank=1. Accessed April 5, 2021.

126. Migliorini D and Dutoit V: ATIM-21. IMA950 peptide-based vaccine adjuvanted with poly-ICLC in combination with standard therapy in newly diagnosed HLA-A2 glioblastoma patients: Preliminary results, Neuro Oncol 18 (Suppl 6): vi22, 2016.

127. Chang CN, Huang YC, Yang DM, Kikuta K, Wei KJ, Kubota T and Yang WK: A phase I/II clinical trial investigating the adverse and therapeutic effects of a postoperative autologous dendritic cell tumor vaccine in patients with malignant glioma. J Clin Neurosci 18: 1048-1054, 2011.

128. Phuphanich S, Wheeler CJ, Rudnick JD, Mazer M, Wang H, Nuño MA, Richardson JE, Fan X, Ji J, Chu RM, et al: Phase I trial of a multi-epitope-pulsed dendritic cell vaccine for patients with newly diagnosed glioblastoma. Cancer Immunol Immunother 62: 125-135, 2013.

129. Wick W and van den Bent MJ: First results on the DCVax phase III trial: Raising more questions than providing answers. Neuro Oncol 20: 1283-1284, 2018.

130. Polyzoidis S and Ashkan K: DCVax ${ }^{\circledR}$-L-developed by Northwest Biotherapeutics. Hum Vaccin Immunother 10: 3139-3145, 2014.

131. Van Gool SW, Makalowski J, Fiore S, Sprenger T, Prix L, Schirrmacher V and Stuecker W: Randomized controlled immunotherapy clinical trials for GBM challenged. Cancers (Basel) 13: 32, 2020.

132. Wick W, Fricke H, Junge K, Kobyakov G, Martens T, Heese O, Wiestler B, Schliesser MG, von Deimling A, Pichler J, et al: A phase II, randomized, study of weekly APG101+reirradiation versus reirradiation in progressive glioblastoma. Clin Cancer Res 20: 6304-6313, 2014

133. Wick W, Krendyukov A, Junge $\mathrm{K}$, Höger $\mathrm{T}$ and Fricke $\mathrm{H}$ Longitudinal analysis of quality of life following treatment with asunercept plus reirradiation versus reirradiation in progressive glioblastoma patients. J Neurooncol 145: 531-540, 2019.

134. Lassman AB, van den Bent MJ, Gan HK, Reardon DA, Kumthekar P, Butowski N, Lwin Z, Mikkelsen T, Nabors LB, Papadopoulos KP, et al: Safety and efficacy of depatuxizumab mafodotin + temozolomide in patients with EGFR-amplified, recurrent glioblastoma: Results from an international phase I multicenter trial. Neuro Oncol 21: 106-114, 2019.

135. van den Bent M, Gan HK, Lassman AB, Kumthekar P, Merrell R, Butowski N, Lwin Z, Mikkelsen T, Nabors LB, Papadopoulos KP, et al: Efficacy of depatuxizumab mafodotin (ABT-414) monotherapy in patients with EGFR-amplified, recurrent glioblastoma: Results from a multi-center, international study. Cancer Chemother Pharmacol 80: 1209-1217, 2017.

136. Phuphanich S, Raizer J, Chamberlain M, Canelos P, Narwal R, Hong S, Miday R, Nade M and Laubscher K: Phase II study of MEDI-575, an anti-platelet-derived growth factor- $\alpha$ antibody, in patients with recurrent glioblastoma. J Neurooncol 131: 185-191, 2017. 
137. Caster JM, Patel AN, Zhang T and Wang A: Investigational nanomedicines in 2016: A review of nanotherapeutics currently undergoing clinical trials. Wiley Interdiscip Rev Nanomed Nanobiotechnol 9, 2017.

138. Mozhei O, G Teschemacher A and Kasparov S: Viral vectors as gene therapy agents for treatment of glioblastoma. Cancers (Basel) 12: 3724, 2020

139. Banerjee K, Núñez FJ, Haase S, McClellan BL, Faisal SM, Carney SV, Yu J, Alghamri MS, Asad AS, Candia AJN, et al Current approaches for glioma gene therapy and virotherapy. Front Mol Neurosci 14: 621831, 2021.

140. Caffery B, Lee JS and Alexander-Bryant AA: Vectors for glioblastoma gene therapy: Viral \& non-viral delivery strategies. Nanomaterials (Basel) 9: 105, 2019.

141. Rubsam LZ, Boucher PD, Murphy PJ, KuKuruga M and Shewach DS: Cytotoxicity and accumulation of ganciclovir triphosphate in bystander cells cocultured with herpes simplex virus type 1 thymidine kinase-expressing human glioblastoma cells. Cancer Res 59: 669-675, 1999.

142. Clinical Trials: Gene Therapy for the Treatment of Brain Tumors. Available from: https://clinicaltrials.gov/ct2/show/ NCT00001328. Accessed January 20, 2021.

143. Ji N, Weng D, Liu C, Gu Z, Chen S, Guo Y, Fan Z, Wang X, Chen J, Zhao Y, et al: Adenovirus-mediated delivery of herpes simplex virus thymidine kinase administration improves outcome of recurrent high-grade glioma. Oncotarget 7: 4369-4378, 2016.

144. Clinical Trials: HSV-tk and XRT and Chemotherapy for Newly Diagnosed GBM. Available from: https://clinicaltrials. gov/ct2/show/NCT03603405.

145. Zadeh G, Bota D, Cachia D, Landolfi J, Schiff D, Vogelbaum MA, Walbert T, Tran D, Chu A, Das A, et al: PC3-151 Toca 5: A phase 2/3 randomized, open-label study of Toca 511, a retroviral replicating vector, combined with Toca FC versus standard of care in patients undergoing planned resection for recurrent glioblastoma (GBM) or anaplastic astrocytoma (AA) (NCT02414165). Can J NeurolSci 43 (Suppl 4): S17, 2016.

146. Cloughesy TF, Landolfi J, Hogan DJ, Bloomfield S, Carter B Chen CC, Elder JB, Kalkanis SN, Kesari S, Lai A, et al: Phase 1 trial of vocimagene amiretrorepvec and 5-fluorocytosine for recurrent high-grade glioma. Sci Transl Med 8: 341ra75, 2016

147. Chiocca EA, Yu JS, Lukas RV, Solomon IH, Ligon KL, Nakashima H, Triggs DA, Reardon DA, Wen P, Stopa BM, et al Regulatable interleukin-12 gene therapy in patients with recurrent high-grade glioma: Results of a phase 1 trial. Sci Trans Med 11: eaaw5680, 2019.

148. Clinical Trials: Study of Ad-RTS-hIL-12 + veledimex in combination with cemiplimab in subjects with recurrent or progressive glioblastoma. Available from: https://clinicaltrials. gov/ct2/show/NCT04006119. Accessed February 3, 2021

149. Kim SS, Rait A, Kim E, Pirollo KF and Chang EH: A tumor-targeting p53 nanodelivery system limits chemoresistance to temozolomide prolonging survival in a mouse model of glioblastoma multiforme. Nanomedicine 11: 301-311, 2015

150. Clinical Trials: Phase II study of combined temozolomide and SGT-53 for treatment of recurrent glioblastoma. Available from https://clinicaltrials.gov/ct2/show/NCT02340156. Accessed February 3, 2021

151. Kumthekar P, Rademaker A, Ko C, Dixit K, Schwartz MA, Sonabend AM, Sharp L, Vincas Lukas R, Stupp R, Horbinski C, et al: A phase 0 first-in-human study using NU-0129: A gold base spherical nucleic acid (SNA) nanoconjugate targeting BCL2L12 in recurrent glioblastoma patients. J Clin Oncol 37 (Suppl 15): S3012, 2019.

152. Lacroix J, Leuchs B, Li J, Hristov G, Deubzer HE, Kulozik AE, Rommelaere J, Schlehofer JR and Witt O: Parvovirus H1 selectively induces cytotoxic effects on human neuroblastoma cells. Int J Cancer 127: 1230-1239, 2010.

153. Sevastre AS, Horescu C, Baloi CS, Cioc CE, Vatu BI, Tuta C, Artene SA, Danciulescu MM, Tudorache S and Dricu A: Benefits of nanomedicine for therapeutic intervention in malignant diseases. Coatings 9: 628, 2019.

154. Carapancea M, Alexandru O, Fetea AS, Dragutescu L, Castro J, Georgescu A, Popa-Wagner A, Bäcklund ML, Lewensohn R and Dricu A: Growth factor receptors signaling in glioblastoma cells: Therapeutic implications. J Neurooncol 92: 137-147, 2009

155. Alexandru O, Dragutescu L, Tataranu L, Ciubotaru V, Sevastre A, Georgescu AM, Purcaru O, Danoiu S, Bäcklund LM and Dricu A: Helianthin induces antiproliferative effect on human glioblastoma cells in vitro. J Neurooncol 102: 9-18, 2011.
156. Alexandru O, Sevastre AS, Castro J, Artene SA, Tache DE, Purcaru OS, Sfredel V, Tataranu LG and Dricu A: Platelet-derived growth factor receptor and ionizing radiation in high grade glioma cell lines. Int J Mol Sci 20: 4663, 2019.

157. Sevastre AS, Buzatu IM, Baloi C, Oprita A, Dragoi A, Tataranu LG, Alexandru O, Tudorache S and Dricu A: ELTD1-an emerging silent actor in cancer drama play. Int J Mol Sci 22: 5151, 2021.

158. Weyerhäuser P, Kantelhardt SR and Kim EL: Re-purposing chloroquine for glioblastoma: Potential merits and confounding variables. Front Oncol 8: 335, 2018.

159. Mazurek M, Litak J, Kamieniak P, Kulesza B, Jonak K, Baj J and Grochowski C: Metformin as potential therapy for high-grade glioma. Cancers (Basel) 12: 210, 2020.

160. Karamanakos PN, Trafalis DT, Papachristou DJ, Panteli ES, Papavasilopoulou M, Karatzas A, Kardamakis D, Nasioulas G and Marselos M: Evidence for the efficacy of disulfiram and copper combination in glioblastoma multiforme-A propos of a case. J BUON 22: 1227-1232, 2017.

161. Sathornsumetee S, Desjardins A, Vredenburgh JJ, McLendon RE, Marcello J, Herndon JE, Mathe A, Hamilton M, Rich JN, Norfleet JA, et al: Phase II trial of bevacizumab and erlotinib in patients with recurrent malignant glioma. Neuro Oncol 12: 1300-1310, 2010.

162. Wen PY, Chang SM, Lamborn KR, Kuhn JG, Norden AD, Cloughesy TF, Robins HI, Lieberman FS, Gilbert MR, Mehta MP, et al: Phase I/II study of erlotinib and temsirolimus for patients with recurrent malignant gliomas: North American brain tumor consortium trial 04-02. Neuro Oncol 16: 567-578, 2014

163. Clinical Trials: Temsirolimus and Perifosine in Treating Patients With Recurrent or Progressive Malignant Glioma. Available from: https://clinicaltrials.gov/ct2/show/results/NCT01051557. Accessed August 1,2021.

164. Reardon DA, Desjardins A, Vredenburgh JJ, Gururangan S, Friedman AH, Herndon JE II, Marcello J, Norfleet JA, McLendon RE, Sampson JH and Friedman HS: Phase 2 trial of erlotinib plus sirolimus in adults with recurrent glioblastoma. J Neurooncol 96: 219-230, 2010.

165. Chheda MG, Wen PY, Hochberg FH, Chi AS, Drappatz J, Eichler AF, Yang D, Beroukhim R, Norden AD, Gerstner ER, et al: Vandetanib plus sirolimus in adults with recurrent glioblastoma: Results of a phase I and dose expansion cohort study. J Neurooncol 121: 627-634, 2015.

166. Peereboom DM, Ahluwalia MS, Ye X, Supko JG, Hilderbrand SL, Phuphanich S, Nabors LB, Rosenfeld MR, Mikkelsen T and Grossman SA; New Approaches to Brain Tumor Therapy Consortium: NABTT 0502: A phase II and pharmacokinetic study of erlotinib and sorafenib for patients with progressive or recurrent glioblastoma multiforme. Neuro Oncol 15: 490-496, 2013.

167. Sousa F, Moura RP, Moreira E, Martins C and Sarmento B: Therapeutic monoclonal antibodies delivery for the glioblastoma treatment. Adv Protein Chem Struct Biol 112: 61-80, 2018

168. Gilbert LA, Horlbeck MA, Adamson B, Villalta JE, Chen Y, Whitehead EH, Guimaraes C, Panning B, Ploegh HL, Bassik MC, et al: Genome-scale CRISPR-mediated control of gene repression and activation. Cell 159: 647-661, 2014

169. Rosenthal M, Curry R, Reardon DA, Rasmussen E, Upreti VV, Damore MA, Henary HA, Hill JS and Cloughesy T: Safety, tolerability, and pharmacokinetics of anti-EGFRvIII antibody-drug conjugate AMG 595 in patients with recurrent malignant glioma expressing EGFRvIII. Cancer Chemother Pharmacol 84: 327-336, 2019.

170. Damore MA, Coberly SK, Wakamiya K, Webster S, Tanna V, Xu X, Klement I, Welcher R, Kiaei P, Liu Y, et al: An EGFRvIII-specific IHC IUO test for patient selection in AMG 595 phase I trial. J Clin Oncol 31 (Suppl 15): S2071, 2013.

171. Hamblett KJ, Kozlosky CJ, Siu S, Chang WS, Liu H, Foltz IN, Trueblood ES, Meininger D, Arora T, Twomey B, et al: AMG 595, an anti-EGFRvIII antibody-drug conjugate, induces potent antitumor activity against EGFRvIII-expressing glioblastoma. Mol Cancer Ther 14: 1614-1624, 2015.

172. Diaz-Miqueli A, Blanco R, Lemm M, Fichtner I, LeónK and Montero E: Preclinical efficacy of nimotuzumab, an anti-EGFR monoclonal antibody as a single agent therapy in human GBM U87MG xenografts. J Cancer Ther 3: 245-255, 2012.

173. Solomón MT, Selva JC, Figueredo J, Vaquer J, Toledo C, Quintanal N, Salva S, Domíngez R, Alert J, Marinello JJ, et al: Radiotherapy plus nimotuzumab or placebo in the treatment of high grade glioma patients: Results from a randomized, double blind trial. BMC Cancer 13: 299, 2013 
174. Westphal M, Heese O, Steinbach JP, Schnell O, Schackert G, Mehdorn M, Schulz D, Simon M, Schlegel U, Senft C, et al: A randomised, open label phase III trial with nimotuzumab, an anti-epidermal growth factor receptor monoclonal antibody in the treatment of newly diagnosed adult glioblastoma. Eur J Cancer 51: 522-532, 2015.

175. Reilly EB, Phillips AC, Buchanan FG, Kingsbury G, Zhang Y, Meulbroek JA, Cole TB, DeVries PJ, Falls HD, Beam C, et al: Characterization of ABT-806, a humanized tumor-specific anti-EGFR monoclonal antibody. Mol Cancer Ther 14: 1141-1151, 2015.

176. Gan HK, Reardon DA, Lassman AB, Merrell R, van den Bent M, Butowski N, Lwin Z, Wheeler H, Fichtel L, Scott AM, et al: Safety, pharmacokinetics, and antitumor response of depatuxizumab mafodotin as monotherapy or in combination with temozolomide in patients with glioblastoma. Neuro Oncol 20: 838-847, 2018.

177. Singh SK, Hawkins C, Clarke ID, Squire JA, Bayani J, Hide T, Henkelman RM, Cusimano MD and Dirks PB: Identification of human brain tumour initiating cells. Nature 432: 396-401, 2004.

178. Chadwick M, Huselid E, Bartucci M, Patrizii M, Jara K, Mehta M, Gilleran J, Augeri D and Sabaawy H: Abstract 3073: Development of novel BMI1 inhibitors targeting glioblastoma stem-like cells abstract. Cancer Res 79 (Suppl 13): S3073, 2019.

179. Affinito A, Quintavalle C, Esposito CL, Roscigno G, Vilardo C, Nuzzo S, Vitiani LR, De Luca G, Minic Z, Giannetti S, et al 1998P-The discovery of RNA-aptamers that selectively bind and inhibit glioblastoma stem cells by targeting EphA2. Ann Oncol 30: v802, 2019.

180. Kouri FM, Ritner C and Stegh AH: miRNA-182 and the regulation of the glioblastoma phenotype-toward miRNA-based precision therapeutics. Cell Cycle 14: 3794-3800, 2015.

181. Johnston MJ, Nikolic A, Ninkovic N, Guilhamon P, Cavalli FMG, Seaman S, Zemp FJ, Lee J, Abdelkareem A, Ellestad K, et al: High-resolution structural genomics reveals new therapeutic vulnerabilities in glioblastoma. Genome Res 29: 1211-1222, 2019

182. Wang DG, Fan JB, Siao CJ, Berno A, Young P, Sapolsky R, Ghandour G, Perkins N, Winchester E, Spencer J, et al: Large-scale identification, mapping, and genotyping of single-nucleotide polymorphisms in the human genome. Science 280: 1077-1082, 1998.

183. Fisher JP and Adamson DC: Current FDA-approved therapies for high-grade malignant gliomas. Biomedicines 9: 324, 2021

184. Kirson ED, Dbalý V, Tovarys F, Vymazal J, Soustiel JF, Itzhaki A, Mordechovich D, Steinberg-Shapira S, Gurvich Z, Schneiderman R, et al: Alternating electric fields arrest cell proliferation in animal tumor models and human brain tumors. Proc Natl Acad Sci USA 104: 10152-10157, 2007.

185. Frenster JD, Desai S and Placantonakis DG: In vitro evidence for glioblastoma cell death in temperatures found in the penumbra of laser-ablated tumors. Int J Hyperthermia 37: 20-26, 2020

186. Rennert RC, Khan U, Bartek J, Tatter SB, Field M, Toyota B, Fecci PE, Judy K, Mohammadi AM, Landazuri P, et al: Laser ablation of abnormal neurological tissue using robotic neuroblate system (LAANTERN): Procedural safety and hospitalization. Neurosurgery 86: 538-547, 2020.
187. Branter J, Basu S and Smith S: Tumour treating fields in a combinational therapeutic approach. Oncotarget 9: 36631-36644, 2018

188. Hauschild A, Grob JJ, Demidov LV, Jouary T, Gutzmer R, Millward M, Rutkowski P, Blank CU, Miller WH Jr, Kaempgen E, et al: Dabrafenib in BRAF-mutated metastatic melanoma: A multicentre, open-label, phase 3 randomised controlled trial. Lancet 380: 358-365, 2012.

189. Peterson YK and Luttrell LM: The diverse roles of arrestin scaffolds in $\mathrm{G}$ protein-coupled receptor signaling. Pharmacol Rev 69: 256-297, 2017.

190. DeWire SM, Kim J, Whalen EJ, Ahn S, Chen M and Lefkowitz RJ: Beta-arrestin-mediated signaling regulates protein synthesis. J Biol Chem 283: 10611-10620, 2008.

191. Artene SA, Folcuti C and Dricu A: $\beta$-arrestin 1 overexpression increases temozolomide resistance in human malignant glioma cells. Curr Health Sci J 43: 112-119, 2017.

192. Horescu C and Artene SA: The effect of beta-arrestin 1 transfection on proliferation and temozolomide treatment response in HGG cells. Medico Oncol 1: 1-9, 2020.

193. Blomquist MR, Ensign SF, D'Angelo F, Phillips JJ, Ceccarelli M, Peng S, Halperin RF, Caruso FP, Garofano L, Byron SA, et al: Temporospatial genomic profiling in glioblastoma identifies commonly altered core pathways underlying tumor progression. Neurooncol Adv 2: vdaa078, 2020.

194. White K, Connor K, Clerkin J, Murphy BM, Salvucci M, O'Farrell AC, Rehm M, O'Brien D, Prehn JHM, Niclou SP, et al: New hints towards a precision medicine strategy for IDH wild-type glioblastoma. Ann Oncol 31: 1679-1692, 2020.

195. Liu L, Wang G, Wang L, Yu C, Li M, Song S, Hao L, Ma L and Zhang Z: Computational identification and characterization of glioma candidate biomarkers through multi-omics integrative profiling. Biol Direct 15: 10, 2020.

196. Duan R, Gao L, Gao Y, Hu Y, Xu H, Huang M, Song K, Wang $\mathrm{H}$, Dong Y, Jiang C, et al: Evaluation and comparison of multi-omics data integration methods for cancer subtyping. PLoS Comput Biol 17: el009224, 2021.

197. Popescu SO, Costachi A, Cioc CE, Buteica A and Dricu A: Iron oxide magnetic nanoparticles as drug delivery systems for brain cancer treatment. Medico Oncol 2: 55-66, 2021.

198. Saenz-Antoñanzas A, Auzmendi-Iriarte J, Carrasco-Garcia E, Moreno-Cugnon L, Ruiz I, Villanua J, Egaña L, Otaegui D, Samprón N and Matheu A: Liquid biopsy in glioblastoma: Opportunities, applications and challenges. Cancers (Basel) 11: 950, 2019.

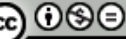

This work is licensed under a Creative Common Attribution-NonCommercial-NoDerivatives 4.0 International (CC BY-NC-ND 4.0) License. 